\title{
Transatlantica
}

Revue d'études américaines. American Studies Journal

$1 \mid 2012$

Le roman policier, littérature transatlantique / Maisons

Hantées

\section{Portals and Pulps: Orwell, Hoggart, "America," and the Uses of Gangster Fiction}

John Fraser

\section{(2) OpenEdition}

\section{Journals}

Édition électronique

URL : https://journals.openedition.org/transatlantica/5727

DOI : $10.4000 /$ transatlantica.5727

ISSN : 1765-2766

Éditeur

Association française d'Etudes Américaines (AFEA)

Référence électronique

John Fraser, « Portals and Pulps: Orwell, Hoggart, "America," and the Uses of Gangster Fiction »,

Transatlantica [En ligne], 1 | 2012, mis en ligne le 16 janvier 2013, consulté le 31 janvier 2023. URL

http://journals.openedition.org/transatlantica/5727 ; DOI : https://doi.org/10.4000/transatlantica. 5727

Ce document a été généré automatiquement le 31 janvier 2023.

\section{(c) (i) $\odot$}

Creative Commons - Attribution - Pas d'Utilisation Commerciale - Pas de Modification 4.0 International - CC BY-NC-ND 4.0

https://creativecommons.org/licenses/by-nc-nd/4.0/ 


\title{
Portals and Pulps: Orwell, Hoggart, "America," and the Uses of Gangster Fiction
}

\author{
John Fraser
}

For Benoît Tadié

“[...] the American ideal, the 'he-man,' the 'tough-guy,' the gorilla who puts everything right by socking everybody else on the jaw [...]" George Orwell, “Boys' Weeklies," March 11, 1940

(Complete Works, XII, 71)

"[The] titles alone drove my blood wild-Torment for Trixy-Hotsy, You'll be Chilled-and on the cover a vivid blonde, blouse ripped, skirt hitched up to her thighs, struggling sweetly against chains, ropes and a gag-and in the top right hand corner, set in a small circle, like a medallion, the silhouette presumably of Hank himself, trench coat open, trilby tilted back, a cigarette hanging from the corner of his mouth." Simon Gray (1936-2008), quoted in "Hank Janson," Wikipedia, about his youthful reading. "Only we didn't use a cob. We made him wish we had used a cob." William Faulkner, Sanctuary (1931) 


\section{Part One}

\section{Introductory}

2 In Ernst Jünger's On the Marble Cliffs, which appeared in the same year as No Orchids for Miss Blandish (1939), the narrator and his brother find themselves gazing down upon a barn in a clearing.

Over the dark door on the gable-end a skull was nailed fast, showing its teeth and seeming to invite entry with its grin. Like a jewel in its chain, it was the central link of a narrow gable frieze which appeared to be formed of brown spiders. Suddenly we guessed that it was fashioned of human hands fastened to the wall. So clearly did we see this that we picked out the little peg driven through the palm of each one. (73-74)

Within the dark interior they glimpse a flaying bench and swarms of flies buzzing around "pale fungoid shapes" (74) while a whistling dwarf pounds and scrapes You would not want to venture through the portal of that barn, any more than through the doorway of the homestead house in The Texas Chain Saw Massacre. But you would wonder.

3 Anything can be a portal, hinting at powerful new possibilities.

4 A single paragraph can lodge itself in one's mind-a single sentence, even ("We made him wish we had used a cob."). Portals can admit bodies and minds into Secret Gardens or Houses of Pain. On a summer evening in deserted downtown Manhattan, a door admitted us, one by one, into a dim interior where King Pentheus, in Dionysus in 1969, would be torn apart fictively by literally naked maenads.

In H.G. Wells' "The Door in the Wall," a successful politician tells the narrator about being haunted by glimpses of a door through which as a child he'd passed one day into pastoral beatitude. Next day, his body is found down below a door in the hoarding surrounding an excavation.

There are doors on the Web that you'd best not click onto.

7 But who (among the survivors) would have chosen to remain on this side of the wall in King Kong?

8 For Charlie Marlow in Heart of Darkness, the portal was a map of the Congo in a shop window, creating the urge to go the limit, to find out. The $19^{\text {th }}$ century was haunted by the dark continent of Sade. The very words "unthinkable" and "unspeakable" are haunting.

9 Here in this article I am mainly interested in what Steve Holland in his The Mushroom Jungle; a History of Postwar Paperback Publishing (1993) dubbed the Mushroom Jungle, the plethora of "low" paperbacks, plus some hardcovers, turned out by largely below-stairs British publishers between 1946 and about 1954, lots of their covers expensive collectibles now, by British authors with American-sounding pseudonyms like Darcy Glinto, Spike Morelli, Al Bocca, Ben Sarto, and Hank Janson (pronounced Yanson).

\section{Hoggart}


There is a memorable portal in Richard Hoggart's The Uses of Literacy (1957), apropos of the Jungle, in the section "Sex-and-Violence Novels." Apparently, out there beyond the Skull-Island culture wall you will encounter monstrosities like:

And all the time old Liz squatted near the fire like a moulting old parrot. Her eyes were nearly lost in circles of puffy fat with red rings around them. Her cheeks were cracked in lines were powder had stuck on and gone dirty. Her stockings were rolled down to her knees, and her knees were white like uncooked pastry. She wore an old purple lace dress, tight and bulgy round her sack-like body. Her hams were like hams going blue and bad.

"Time we fixed up Molony" said Lefty at last.

He tossed away the butt of his cigarette and went over to where Molony was fastened to the centre-post. Molony had pretty well recovered from that smack on the carotid artery when he'd gone black and dropped. By now his face was just yellow and strained with panic, and his eyes stuck out like a strangled rabbit's.

"You can't do this to me, Lefty," he said.

Lefty went up to Molony, and carefully showed him the knife, then he let him see it placed against his stomach. Then Lefty pressed gently but firmly like a butcher going into meat. He was still grinning straight into Molony's eyes when Molony let out one rattling scream and sagged. Lefty sniggered then, pulled out the knife and wiped it very carefully. "Now for the dame," he said.

The girl felt herself retching with horror as the waves of panic and pain succeeded each other. Between whiles Butch had been slapping her hard across the eyes with his open hand, and every so often he'd made as though to drive his knee into her groin.

By now her dress was torn down to her stomach and her négligée ripped and soiled. As her almost naked breasts rose and fell, Lefty, from near the stove, watched out of the corner of his eyes and every so often spat deliberately into the embers. After a while the red waves of pain began to overwhelm her, but just before she went under she saw him get up with a new and horrible look in his eyes ... She began giving little agonised gurgling sounds and her legs twitched in spasms. (218; ellipses sic)

12 The Jungle, in Hoggart's presentation, is beyond the pale.

These are novels of violent sex, in which sex seems to be regarded as thrilling only when it is sadistic. There must be violence all the time: between men, prolonged arm-twistings, razor-slashings, moans, with embraces only in bloody bites on both side (the usual number seems to be two violent sexual contacts in each novel, as well as a few single-sex beatings up); long drawn out beatings with rubber tubes: "He had a wound in his cheek that looked like a mouth that wouldn't stop bleeding." When man meets woman the air is heavy with violence, with druginspired moans, with embraces ending in bloody bites on both sides ... (213)

13 However, my own experience during several months in the Jungle was a good deal different from Hoggart's.

14 The holdings of Jungle books in the British Library and one or two others are far from complete, and many titles obviously exist now only in a few private collections. So it's possible that Hoggart, born in 1918, read and accurately remembered (or owned?) books that never came my way. But as I explain elsewhere, there are grounds for supposing that the two-hundred-odd Jungle books in my possession are reasonably representative. (See Notes.)

15 And my own reading simply doesn't correspond to Hoggart's indictment, including:

We are in and of this world of the fierce alleyway-assault, the stale disordered bed, the closed killer car, the riverside warehouse knifing. We thrill to those in themselves; there is no way out, nothing else; there is no horizon and no sky. The 
world, consciousness, man's ends, are this-this constricted and overheated horror.

(220) everything, in a culture unrelentingly under siege. With all of it coming from elsewhere. The intrusive elements-the too bright milk bars, the overplayed juke boxes, the snappy newspaper one-liners, the disingenuous flattery of the common man, the tacky pop songs, those awful sex-'n-violence paperbacks, the suits with padded shoulders, and so on and so forth-are all essentially "American." 


\section{Orwell}

You would never guess that there was anything American to be admired-movies and jazz are never mentioned-or that American know-how and commitment and courage had made possible a wartime victory that Britain could never have achieved on its own.

And in this it was a book of the 1950s, in which Britain, exhausted by the War, and in hock to the Yanks for debts incurred during the Lend-Lease programme begun in 1941, was trying to rediscover its identity.

Of the better-known new writers, Thom Gunn went American, and to America, and Philip Larkin, the best of them, explored endlessly the "where" and "what" of who he was and wasn't, and did marvellous jazz reviewing in the Sixties, and wrote those lovely poems "To Sidney Bechet" and "Love Songs [sheet music] in Age."

9 For others, it was a turning away from Americanism-Kingsley Amis's Lucky Jim (1954) (whose cynical philistinism I found unfunny while doing seriously a serious doctorate at the University of Minnesota); John Osborne's Look Back in Anger (1956)(with its hateful self-pity that could have been mine had I remained in England), and the more or less screwed-up working-class lives of Alan Sillitoe's Saturday Night and Sunday Morning (1958) and John Braine's Room at the Top (1959), in both of which no one ever goes to or talks about a movie or listens to jazz.

Plus Harold Pinter's The Homecoming in 1964, with its skewed antithesis. On the one hand, there's the squeaky-clean life of an imagined American campus, from which, and from her kids and dead-on-the-page academic husband Teddy, the erstwhile English nude "model" Ruth detaches herself without a twinge. And on the other is the warm, aggressive, loquacious, sub-criminal, real life of an East End male Jewish family in which she'll queen it as Circe-on-the-game. And intellection is mere wheel-spinning wordgames or empty professionalism.

Hoggart's antidotes to the awfulness that he describes are oddly unspecific, apart from an intimation that more censorship (presumably of the sex-'n-violence nasties) mightn't be such a bad thing.

He says nowt about Culture and Environment and Denys Thompson's journal English in Schools (subsequently The Use of English), in which, starting in 1949, teachers and the teachers of teachers were concerned with strategies for giving kids from early on, as both readers and writers, a sense of the rich resources of the English language. Which is to say, antidotes to the very impoverishment that he himself (ah, the lone heroic Northern voice!) deplored.

Nor, in his jeremiad, are there any nascent Sixties energies to be discerned, any generative powers within that warm, low-aspiration communality from which a scholarship boy discovering high Culture had to wrench himself free.

You could never have predicted the Beatles from The Uses of Literacy.

$35 \mathbf{V}$

Behind Hoggart's indictment, of course, was Orwell in "Raffles and Miss Blandish" (1944), “Boys' Weeklies” (1940), and some remarks elsewhere.

At this late date I don't need to recapitulate the details of his polemic against No Orchids, with on the one hand, in the books of E.W. Hornung about gentleman-thief A.J. 
Raffles, the older English chivalric tradition in which there are things that a gentleman simply Will Not Do; and on the other, across the Atlantic, American Social Darwinism, with woe to the loser and "unheard of" cruelties.

As I put it in Found Pages, it was all essentially there in his 1936 review of Paul Cain's Hammettesque Fast One.

The blurb [Orwell says] describes it as "a whirlwind of double-crossing, ambush and murder." Here is a specimen paragraph:

The little man came into the room quickly and kicked the side of Kells' head very hard. Kells relaxed his grip on Rose and Rose stood up. He brushed himself and went over and kicked Kells' head and face several times. His face was dark and composed and he was breathing hard. He kicked Kells very carefully, drawing his foot back and aiming, and then kicking very accurately and hard.

This kind of disgusting rubbish (hailed as "genius" when it comes in a slightly more refined form in Hemingway) is growing commoner and commoner. Some of the threepenny "Yank Mags" which you buy at Woolworth's now consist of nothing else. Please notice the sinister change that has come over an important subdepartment of English fiction. There was, God knows, enough physical brutality in the novels of Fielding, Meredith, Charles Reade, etc, but

our masters then

were still at least our countrymen

In the old-style English novel you knocked your man down and then chivalrously waited for him to get up before knocking him down again. In the modern American version he is no sooner down than you take the opportunity of jumping on his face (X 475).

However, Orwell's account of No Orchids is simply wrong in a number of ways. I won't be continually quoting from myself, but occasionally it saves time. As I say in Found Pages:

No Orchids is a novel with no Hardyesque coincidences and no hints of Fate or any other determinism at work, either pro or con. Basically, people are defeated and/or killed because others with whom they are in conflict, on either side of the law, are stronger, smarter, and more ruthless than they are.

Orwell considered this Fascism. But since there are no intimations that the strong ought to prevail simply by virtue of being stronger, I don't think it is, and it seems to me a healthier attitude than the programmatic noir pessimism of the James M. Cain variety.

Nor, Orwell to the contrary, are the characters simply seeking power over others. What they're mainly after is money-money and the security that it can bring.

The ultra-violences pilloried by Orwell are indeed unforgettable, especially slim's killing of the minor hoodlum Riley ("The knife went in slowly as if it were going into butter."), the third-degreeing of Eddie Schultz, and, at the outset, the killing by Bailey of Miss Blandish's playboy date for the evening, who has drunkenly knocked him down during the snatch.

But despite their intensity, and their contributions to the atmosphere of anxiety, such incidents take up very little space. For the most part the killings are practical and non-sadistic-eliminating inconvenient witnesses, escaping from cops.

The third-degreeing of Eddie Schultz is practical-the classic scenario of the one man who can lead them to Miss Blandish being a tough egg who won't squeal otherwise.

Orwell's statement that "the police kill off the criminals as cruelly as the angler kills the pike" is a curious way of describing the storming of the town fortress in which the gang blaze away with tommy guns until the end. The police and the F.B.I. have evidently not been strong-arming their way to a solution before Blandish brings in Fenner, who cooperates with them. 
Orwell is misleading, too, when he says that "such things as affection, friendship, good nature or even ordinary politeness simply do not enter."

The relationship between Fenner and his perky, playful secretary Paula is charming. Fenner's reassurance to Blandish ('“'ll get those thugs,' he said softly, 'if it's the last thing I do"') is not that of someone simply in it for the money. And at the end he displays considerable sensitivity in his handling of the rescued Miss Blandish, who after three months in the Grissoms' hands will now have to live with unbearable memories.

Orwell is also, it seems to me, needlessly sniffy about the phenomenon of No Orchids being especially popular during the Blitz and ordinary soldiers relaxing with "Action Mags" in combat situations.

What ought they to have been reading? Something by Orwell's favourites like Fielding or George Meredith? One of those "old-style" English novels in which "you knocked your man down and chivalrously waited for him to get up before knocking him down again"?

The reasons for so substantial a skewing are worth enquiring into.

$$
42 \text { VII }
$$
says:

When you read about Mark Twain's Mississippi raftsmen and pilots, or Brett Harte's Western gold-miners, they seem more remote than the cannibals of the Stone Age. The reason is simply that they are free human beings. But it is the same even with the peaceful domesticated America of the Eastern states, the America of Little Women, Helen's Babies, and "Riding Down from Bangor." Life has a buoyant, carefree quality that you can feel as you read, like a physical sensation in your belly (XII, 90) 
where he called Jack London's The Road (1907) a "brilliant little book," and adapted the strategies of London's The People of the Abyss (1903) for Down and Out in Paris and London.

And, an intellectual himself, with a strong interest in Continental intellectuals, he was at ease with the editors and, by implication, readers of the quintessential New-Yorkintellectual Partisan Review.

\section{VIII}

In the wartime Forties, Orwell was obviously voicing an annoyance with things that were annoying others-London in 1943 feeling like an Occupied Country; Yanks better paid and clothed, Yanks obnoxiously drunk, Yanks bad-mannered. Plus, surely, a recognition that the war, after the glory days of El Alamein and the Desert Rats, and with too many British troops bogged down unromantically in Italy, was becoming an American one, at least on the ground.

"Raffles and Miss Blandish" came out in 1944, shortly before D-Day (unmentioned by Orwell) and the prospect of a would-be final settling of accounts with the Germans. It was a time of military "realism," in which you didn't wait till your opponent had climbed to his feet before knocking him down again.

The half-American Churchill, his mother the vibrant, beautiful, extravagant Lady Jennie, had ruthlessly sunk the anchored French Mediterranean warships in 1940 to prevent them from falling into enemy hands, and later gave "Bomber" Harris his head. With Churchill's encouragement, Captains "Dan" Fairbairn and "Bill" Sykes, formerly of the tough Singapore Police,

trained British, American and Canadian Commando forces, along with Ranger candidates in close-combat, pistol-shooting and knife-fighting techniques. Fairbairn emphasized the necessity of forgetting any idea of gentlemanly conduct or fighting fair. "Get tough, get down in the gutter, win at all costs... I teach what is called 'Gutter Fighting.' There's no fair play, no rules except one: kill or be killed," he declared. (See Notes.)

Apparently, "The Germans in 1942 published a pamphlet which portrayed [Sykes'] methods, and used it in neutral countries to enlist sympathy against the diabolical British." (See Notes.)

Such methods would probably have figured in the training programme for the Home Guard, set up by Orwell's friend Tom Wintringham at Osterley Park.

Orwell himself served for three years in the Home Guard, where, drawing on his experience in Spain, he instructed in street-fighting during the period when invasion seemed likely. There is nothing about fair play in his notes ca 1940-42. (XII, 328-340).

The case against playing fair against an enemy who simply ignored the rules was made intensely in 1943 in a speech by Anton Walbrook's refugee good-German to dear blimpish Roger Livesey, with his ingrained belief in "clean fighting, honest soldiery," in the Powell-Pressburger movie The Life and Death of Colonel Blimp, which Orwell must have seen:

"If you preach the rules of the game [the time is 1940] while they use every foul and filthy trick against you, they'll laugh at you, they'll think you're weak, decadent. ... Clive, dear old Clive, this is not a gentleman's war. This time you are fighting for your very existence ... , and if you lose, there won't be a return match next year, perhaps not even for a hundred years."

Transatlantica, 1 | 2012 
(It's deftly counterpointed, in the framing narrative, by the obnoxiousness of the cocksure young second-lieutenant, a peacetime race-car driver, who wrecks a whole military exercise by jumping the gun in order to "win" by his own rules.)

Replying in May 1944 to a pacifist's objections to his printed defense of the saturation bombing of German cities, Orwell himself wrote:

We must either build a better society or continue to do evil. The "peace" to which Miss Brittain wants to return is ultimately based on the truncheon and the machine gun. As to war, you cannot at present avoid it, nor can you genuinely humanise it. You can only, like the pacifist, set up a moral alibi for yourself while continuing to accept the fruits of violence. I would sooner be Air Marshal Harris than Miss Brittain, because he at least knows what he is doing, (XVI, 196).

There was a good deal of uncertainty as to how the Germans should be treated after the war. Roosevelt's Secretary of the Treasury Henry Morgenthau was arguing for a delenda est carthago policy-strip them of their heavy industries and reduce the bastards to the serfdom that they'd planned for Poland and Russia.

The magnanimous Marshall Plan, which in effect gave a practical hand-up to a fallen foe, was far from there at the outset.

63 IX

64 I think that back in 1940 Orwell, who had had an education in Spain about the ineffectiveness of disorderly democracy against Fascist ruthlessness, but was still a pacifist in the Thirties with respect to war with Germany, had been trying to clarify values for himself and others when in "Boys' Weeklies" he contrasted the pacific schoolboy reading of his own boyhood, whose aspirations he understood, with a newer one that he didn't.

And that he continued the clarification with "Raffles and Miss Blandish," in which, in the Raffles part, he detached the chivalric from its John Buchanish base in an Establishment that he loathed. And that, needing an antithesis about realpolitik and Machiavellian power-seeking, he turned to No Orchids and got it wrong.

Moreover, the runaway success of No Orchids must have irritated him, his own nostalgic Coming Up for Air, also out in 1939, not having set the Thames on fire.

And there would appear to have been some bad faith when he complained that "the great majority [of Yank Mags] are quite plainly aimed at sadists and masochists," and observed in a footnote that to "Raffles and Miss Blandish" that, "They are said to have been imported into this country as ballast, which accounted for their low price and crumpled appearance. Since the war the ships have been ballasted with something more useful, probably gravel." (RMB XVI, 352)

68 He himself, he told America's Dwight Macdonald in a letter in 1943, "was a reader of them for years and know their moral atmosphere." (XVI, 25). Back in 1932, when researching into underclass conditions, he'd "bought some tobacco and a 'Yank Mag' against my forthcoming imprisonment" ( $\mathrm{X}, 254)$. At that time an obvious candidate would have been Black Mask, but maybe he was into air-aces and pugilists?

It would be interesting to know if his complete journals contain any references to his exchanging information about toughies with his friend Geoffrey Gorer, author in 1934 of The Revolutionary Ideas of the Marquis de Sade.

As to sadists and masochists, Orwell's first book Down and Out in Paris and London (1933) was spiced up with an introductory White Slave rape episode of considerable power, 
narrated by a fellow dish-washer, that had nothing whatever to do with the rest of the book. "'Ah, how she screamed with what bitter cries of agony. But there was no one to hear them; down there under the streets of Paris we were as secure as at the heart of a pyramid," Charlie recalls, the episode eliciting from Orwell the comment, "He was a curious specimen ...." (I, 10-11).

More importantly, Orwell also failed to see the kind of political novel that No Orchids was.

\section{No Orchids for Miss Blandish}

$72 \mathbf{X}$

No Orchids for Miss Blandish deserves to be on any "Literature-and-Society" reading list for the Thirties. It was not a Fascist novel, as Orwell claimed. It was a novel against Fascism.

The Great War-to-End-Wars, into which Britain had stumbled, had eroded the governing classes' image of themselves as the guardians of a quasi-Roman good order, an image already shaky before the war, what with Irish rebels, window-smashing suffragettes, and radical industrial strikes.

The slaughter in Flanders of appalling numbers of the best and brightest future politicians, lawyers, civil servants, scientists, engineers, philosophers, doctors, teachers, novelists, labour leaders, and so forth made rubbish of ruling class claims to an efficiency that the lower orders were incapable of, and lowered the collective I.Q. in a way from which it never recovered,

Despite the wealth of social thought in Victorian England, there was no hope of any revitalizing thinking emerging from Britain in the Twenties, as D.H. Lawrence knew when in 1919 he and Freda shook its dust from their feet. Germany, the most socially progressive country in the later nineteenth-century, had become hopelessly compromised by its militarists. And the French, being Frogs, and exhausted, and with their peculiar post-1789 hang-ups, didn't count. treatments and rubber truncheons applied to the persons of-who else?-Communists, was not an all-purpose dirty word but an effective system of government. Trains were running on time, swamps were being drained, the Mafia was suppressed, the principle of "Roman" order and imperial energy was being reaffirmed, and Fascism worked better than Democracy when the Crash occurred. It was legitimate, too, Il Duce being officially Prime Minister (and, as events proved, dismissable) under King Victor Emmanuel III. As late as 1936, Orwell could refer in a review to "Mussolini's large body of English worshippers". (X, 523)

And from America, cock-a-hoop with Belleau Wood, and having settled the conflict Over There between the exhausted contenders, and imposed Peace afterwards, and now unequivocally a world player and number-one example of success, came the celebration of unfettered he-man capitalism and consumerism, and the promise of endless ongoing progress and pleasure.

Transatlantica, 1 | 2012 
81 And a welcome was given to American-style hedonism, what with West End musicals (sparked by the Astaires), ragtime, jazz, pop songs, movies and movie stars, and the plethora of often illegal nightclubs (the most famous of them Kate Meyrick's 43 Club) radiating outwards from Leicester Square where the bright rich young, headed by the swinging Prince of Wales, went to drink and-seeking exercise-dance, dance, dance. Orwell comments somewhere that a hedonistic take on life was dominant until the coming of Hitler.

But there were conceptual poisons in the American chalice, over and above the bullying, philistinism, and historical ignorance of the capitalism-consumerist ideology that Leavis and Thompson would go after in 1933 in Culture and Environment.

If what was to be admired in a Social Darwinist world, as in the later $19^{\text {th }}$-century heyday of the Robber Barons, was the deserved success of the fittest, a new brand of winners was among those emerging in Prohibition America, namely Italian gangsters, moving in on the still partly chivalric Irish kind.

And the conflation of gangster-supreme Capone with Mussolini as empire-building figures was problematic with regard to law and order after the $1929 \mathrm{crash}$, the law having been largely in abeyance during the boom and the order now a hollow shell after the bust.

85 An interesting probing goes on in C.S. Forester;s powerful Plain Murder (1930), more "American" than "English" in the decisive violence of its protagonist and the ineffectiveness of the police, with which Forester followed up his very "English" Golden Age Payment Deferred (1926), with its lower-middle-class poisoner and claustrophobic guilt.

Standing in the railway carriage [Morris] constituted what a catholic taste might term a fine figure of a man-big and burly in his big overcoat, with plenty of colour in his dark, rather fleshy cheeks. His large nose was a little hooked; his thick lips were red and mobile; his dark eyes were intelligent but sly. The force of his personality was indubitable, he was clearly a man of energy and courage. (Ch.2, 8)

Charlie Morris and a couple of fellow employees in a London advertising agency face the, in those Depression days, terrifying prospect of the sack (without references) after an office superior catches them out in a bit of chicanery. Morris, seething with energies and ambition denied outlet, and assisted by weak young Reddy and the tougher Oldroyd, shoots the trouble-maker in his garden on Guy Fawkes Night, after which he is promoted to his position, rises in the firm, increases its efficiency, comes up with a brilliant advertising scheme, displays qualities which some might consider those of a great general, and sees the future opening up before him.

Quite a story for someone with only an elementary-school education. And very different from the Hitchcockian paralysis of bank-clerk William Marble in Payment Deferred, unable (with that corpse buried in his garden) to enjoy the fruits of his crime. It wasn't surprising that the young in Depression Britain were interested in highenergy gangsters like Capone, or that Forester himself went on to narratives of martial success like The Gun (1933) and the Hornblower Epos.

But the un-"English" Morris, killing with a pistol in contrast to all those poisoners in the Golden Age classics of resentment and greed, and swelling with vanity, is dangerous. Infuriated by obstacles, and convinced of his infallibility, he disposes of guilt-ridden 
young Reddy in a motorbike "accident," and is soon turning his tigerish gaze on Oldroyd and (with juicier flesh in mind) his own scrawny but still loving wife Mary.

Eventually he goes down (literally), but not from any investigative work (the State is barely present) or the kind of retributive irony, going back to Poe's "The Black Cat," that made Francis Iles' Malice Aforethought (1931) famous, and that would figure, more prominently than Save-Our-Children crusaders recognized, in crime and horror comics. Nor is there any general message in the book about crime's not paying.

So, what about "America"?

\section{XI}

After a flying visit to the States, Edgar Wallace provided in the complex personal interractions of On the Spot (1930/31), both play and novel, an intelligent exploration of the dynamics of Caponism-essentially the Italianate Machiavellianism that had run parallel with the chivalric during the Renaissance and been alarming in England then too.

Towards the end, the Capone surrogate Tony Perelli (more cruel in his treatment of women than Capone appears to have been) gives a speech to police-detective Kelly that must have come off the West End stage at the audience with a Shavian force:

"You're a swell feller-I hand it to you. When you give me the green I pass; when you snap the red I stop. I know where I am with you. But there is only one way of running my racket and that is the way I go, eh? If one man is bumped off, or two men are umped off, what does it matter? Are they innocent? Are they citizens? Tell me! They are hoodlums, murderers, bombers. Hold-up men, vice men, everything! What does it cost to hang them in the state of Illinois? Fifty t'ousand dollars! Fifty grand! Lawyers, jurymen, judges, new trial, new witnesses-eh, it goes on for years before the hangman says 'step on it!' Four hundred people have been bumped off by gangsters-if you like, I am a gangster-by us! We save the State six million dollarssix cartridges for sixty cents, eh? That's cheaper than fifty thousand dollars. Outside the State Legislature there should be a statue to gangsters. We are benefactors-if you like, vermin that prey on vermin. It is unanswerable!" (Ch.XIX, 219)

Not to mention that he and his competitors were businessmen providing large numbers of people with products denied them by blue-nosed, rural-based, anti-Catholic Protestant reformists.

In 1930, too, the left-wing Victor Gollancz, who later published Orwell's The Road to Wigan Pier (1937) and Homage to Catalonia (1938), came out with the American author Charles Francis Coe's novel Gunman as a quality paperback. It presented, largely through conversations and newspaper reports, the successful operations of nosethumbing city-corrupter Antonio Scarvak, and was chosen, I'm sure, because of the Capone/Mussolini nexus plus an awareness of the looming Hitler.

At a banquet given for key figures in law-enforcement and the judicial system, Scarvak

pointed out that there was no possible defence against enemies other than constant offence. And the only possible offensive movement, he declared, was dynamic expansion. To keep others from invading their own domain, Antonio's gang must be the invaders. They could not stand competition, and the one way to overcome it was to stifle it in the roar of machine guns and to proclaim to expiring racketeers the dominance of their own position. (28) Gangs Came (1930), and Wallace's own When the Gangs Came to London (1931) went into 
the question of how an orderly society could or should cope with gangs of criminals playing by different rules.

In Leslie Charteris's The Saint's Getaway (1933), we read:

He settled back in his corner and pulled at the brim of his hat-a broad-shouldered, prematurely old young man of about twenty-eight, with a square jaw and two deep creases running down from his nose and past the corners of his thin mouth. He was one of the first examples of a type of crook that was still new and strange to England, a type that founded itself on the American hoodlum, educated in movie theatres and polished on the raw underworld fiction imported by F.W. Woolwortha type that was breaking into the placid and gentlemanly paths of old-world crime as surely and ruthlessly as Fate. In a few years more his type was no longer to seem strange and foreign, but in those days he was an innovation, respected and feared by his satellites. He had learned to imitate the Transatlantic callousness and pugnacity so well that he was no longer conscious of playing a part. He had the bullying swagger, the taste for ostentatious clothes, the desire for power, and he said "Oh, yeah?" with exactly the right shade of contempt and belligerence. (Part Two, ch. 1)

100 The essential conflict was what one would see later being played out between John Wayne and Richard Attenborough in Brannigan (1975), and in its TV spin-off Dempsey and Makepeace, between "American" short-cuts, with a bit of unfriendly persuasion in the back room, and the rule-following of Scotland Yard types.

With the deglamorizing of big-time gangsters in Roosevelt's post-Prohibition America, and the ugly violences of Sir Oswald Mosley's Blackshirts, the forces of English law-andorder prevailed in the Thirties, coping with smash-and-grab raids, ending the protection rackets on racecourses, outlawing uniformed political demonstrations, and handing out heavy sentences, including the cat-o'-nine-tails, for robbery with violence, especially armed violence.

\section{XII}

But these were reactive domestic moves, continuing normal power relationships. International politics were something else. In "The Storm Cone 1932", Kipling warned that

This is the midnight-let no star Deceive us-dawn is very far.

This is the tempest long foretold-

slow to make head but sure to hold.

And the following year, W.H. Auden (whom Orwell called "a sort of gutless Kipling") lamented in "Out on the Lawn I Lie in Bed,":

Soon through the walls of our content

The gathering flood will force a rent

And taller than a tree

Hold sudden death before our eyes

Whose river dreams long hid the size

And rigours of the sea.

The English governing class, its Roman sense of a civilizing mission (never without its British challengers) seriously undermined by Woodrow Wilson's doctrine of the selfdetermination of peoples, not to speak of its own domination by the French and Americans at Versailles, was simply unable to cope with the fact of Hitlerism and the gangster state. 

read. him down.

Hitler himself was very American-impatient with the old guard, the Prussian army professionals; fascinated with new technologies (campaigning by plane, encouraging imaginative new weaponry); understanding high-precision pageantry; losing himself in Karl May's German Westerns about Old Shatterhand; conceptualizing the Slavic East as the equivalent of America's West; allowing his type-cast henchmen lots of freedom in their own bailiwicks; and going the Valentine's Day Massacre much better in the Night of the Long Knives (1934). An observer in the early Twenties spoke of his going to social events in "his gangster hat and trenchcoat."

Like Capone, he charmed when he wanted to (reviewing Mein Kampf in 1940, Orwell "put it on record that I have never been able to dislike Hitler"), and he lied and broke promises unblushingly. (XII, 116)

There had been a huge rent earlier in Europe's self-image, with the 1914 wartime atrocities in Belgium (colonial brutality transposed into Europe ) that were documented in the Bryce Report (1915) and other volumes. (See my "Propaganda, Atrocities, and the Limits of the Thinkable," http://www.jottings.ca/john/kelly/sbar14.html)

But with peace restored, there was a recoil from the horrors of the trenches, compounded by a Wellsian dread of unpreventable bombing, memorably on display later at Guernica. (Atomic bombs had figured in Wells' 1914 novel The World Set Free.) And there was the self-protective belief of the governing class that Hitler was really OK, and just a normal politician cleverly role-playing in his angers and tirades. Members of civilized societies simply didn't do or believe certain things.

There was no excuse for the ignorance, of course. In 1933, Victor Gollancz published The Brown Book of the Hitler Terror and the Burning of the Reichstag, with a foreword by Lord Marley, Chairman of the World Committee for the Victims of Fascism, in which every kind of atrocious act by the newly in power National Socialists was documented with more eye-witness and first-hand accounts than one would normally choose to

1 Most likely they weren't read by the Tories, who were bent on maintaining good relationships with a government whom they did not want to default on its war debts to Britain, whatever might happen to the French. Or, if glanced at or referred to in passing, weren't believed, just as the documentation in the Bryce Commission's report on alleged German atrocities in Belgium in 1914 had come to be dismissed by pacifists like Lord Ponsonby as mere wartime propaganda.

There is no mention of the Bryce Report in the then-pacifist Orwell's writings in the Thirties, in which (1930-1938) Hitler is mentioned by name only once.

3 As late as April 1936, four months before the Spanish Civil War began, Orwell was speaking of chivalrously allowing your opponent to get up again after you've knocked

4 In The Road to Wigan Pier the following year, he remarked that "We have got to admit that ... Fascism is everywhere advancing." (188)

\section{XIII}

The thrillers of Brandon and others that I mentioned weren't any great shakes, particularly when contrasted with American ones like Hammett's brilliantly cynical Red Harvest (1929) and The Glass Key (1931), the former of which would have a long life, 
metamorphosing via Kurosawa's Yojimbo into Leone's The Man with No Name Trilogy, and eventually Walter Hill's 1996 Last Man Standing.

But after Hitler reoccupied the Rhineland in 1936 with no countermeasure from England and France, some relevant political thrillers started appearing.

Eric Ambler produced two anti-Fascist novels in Uncommon Danger (1937) and Cause for Alarm (1938), with Fascist street beatings in the former and German-type torture (rubber truncheon) in the latter, plus a powerful evocation of the power of that stick of hard rubber in his first novel, Dark Frontier (1936).

The man with the truncheon made a show of hitting the mechanic across the knee with it. The man's head rolled back and he let out a hoarse shout of terror. I understood. A blow on the knee-cap is bad enough at the best of times. When that blow is dealt with a rubber truncheon the pain is unbearable. Moreover, the kneecap does not numb as easily as other parts of the body, so that repetitions of the blow will intensify the agony. (ch. 14)

But journalist Kenton in Uncommon Danger and engineer Nicky Marlow in Cause for Alarm have to be rescued from the Continental dangers into which they've stumbled by charming, resourceful Soviet agent Zaleshoff, a character surely derived from the charming and very effective Communist propagandist Willi Münzenberg.

And the effectiveness of "Carruthers" against Ruritanian baddies in The Dark Frontier is the freak result of a concussion that temporarily transforms exhausted stuffy physics professor Henry Barstow into the upper-class hero of someone's yellow-jacketed Hodder \& Stoughton thriller that he'd happened upon in a hotel lounge.

In A Gun for Sale, in that year, Graham Greene came up with the ersatz Raven, part English race-course gangster, part cold political assassin for hire, part sensitive, harelipped, insufficiently-mothered brooder, and without a moment of credible from-the inside speech locating him in a social group.

With a follow-up in 1938 with Brighton Rock and its vicious little gangster-hero who, oh, you know, being a Catholic, is still superior to shallow secular moralists who want to bring him to justice and save the innocent from him. Plus a rich, successful, condescending, retired gangster, based reportedly on the East End's Darby Sabini.

Greene's oddest work at that time, The Confidential Agent, came out the following year, written, he recalled later, on bennies to boil the pot, and showing it.

The serious part of the book ends on p. 130 of the copy I'm looking at. A Spanish professor of Romance literature, come to England on behalf of the Spanish government to prevent Franco's forces from getting English coal, has one unpleasant experience after another engineered by agents from the other side, including a realistic beating and the murder of a helpful skivvy, and is unable, Kafkaesquely, to persuade Brits that he is who he is, let alone that he hasn't done what he's accused of. The mission fails when the mine-owners agree to sell to the other side.

There's strong writing, credible dialogue, and considerable physicality in there, without the tic-tic-tic of Greene's too often compulsive simile-making, and an interesting section, unfortunately not developed, in which the professor argues that chivalrous Roland in The Song of Roland in fact caused a lot of needless harm and that the true hero was practical-minded Oliver.

But since you can't boil pots with defeats, the novel continues for another 117 pages, with the professor turning into a more feisty and insouciant character, who by the end 
has achieved everything he wants, in an anticipation of Our Man in Havana, with a dash of Evelyn Waugh.

This was a political novel? In 1939? After the Fascists' victory in Spain?

In 1938 Gerald Kersh did a semi underworld novel in Night and the City. But, like Greene's Pinky, his would-be fight-promoting Harry Fabian, in a book very different from the movie, is an underdog loser, as Hitler was still perceived by some as being. A woman remarks of Harry, "He reads American magazines, and pretends, just like a little boy. I don't know why people have to pretend to be American. I suppose it's the films." (ch. 21, 301).

No Orchids for Miss Blandish, also 1939, looks all the better in the contrast.

\section{XIV}

What was most seriously in doubt was the morale of younger members of the governing class when faced with the possibility of war, given the 1933 vote of the Oxford debating Union that it would not fight for King and Country, and the power of English pacifist movements.

The strong and effective English gentleman was not in fact a myth, as witness the remarkable older group, most of them survivors from the trenches, who cooperated in the assault on Everest in the early Twenties, as described in Wade Davis's brilliant Into the Silence (2011).

But there were serious questions as to whether the gentlemanly types in British movies -quintessentially Leslie Howard (half Hungarian), Robert Donat ("of English, Polish, German and French descent" according to Wikipedia), and Michael Redgrave - would be capable of dealing with Nazi professionals, however easily the latter might be outwitted in the movies. And the British Army was much inferior at the top to the German, to the exasperation of Churchill in wartime, hungry for generals who would fight and win, and himself technologically oriented.

Hitchcock's The Lady Vanishes (1938) was an obvious parable, with its train stalled within fascist territories, and its cargo of cricket-obsessed idiots, a let's-be-sensible appeaser, a frantic young woman who's not believed because, well, girls are like that, and a nice but disbelieving Englishman, who keeps women at arm's length with his jolly-decent persiflage; plus efficient baddies and one of those wonderful upper-class British secret agents, a middle-aged lady.

They were lucky to get out of it at all, given how long it took them to make a realistic appraisal of their situation.

\section{$136 \mathbf{X V}$}

1938 was an especially disturbing year, what with Czechoslovakia, the Kristalnacht, the release of Leni Riefenstahl's filming of the Olympic Games, the published transcript of the Moscow Trials, and H.J. Timperley's What War Means: the Japanese Terror in China; a Documentary, a volume revealing in horrific detail what had occurred the previous year in the all-too-literal as well as figurative Rape of Nanking.

(My father bought a used 1928 Overland Whippet that year in perfect condition for ten pounds, in which to evacuate us if needs be.)

Peter Cheyney had created a violent American good guy in 1936 with Lemmy Caution, who reports of a cocky young hoodlum in This Man is Dangerous (1936): 
This guy gets up and spits out a coupla teeth. I walk round to him an' I sit him down on the chair again. I pick the chair and him up, and' I throw the whole outfit against the wall. The chair busts an' this guy falls down on the floor. He is covered with blood an' he is not looking too hot. (ch.3, 44)

As I said of it online, "The first six chapters are remarkably violent, and at times in the present-past-tense narration one catches glimpses of the Carter of Ted Lewis's Jack Carter's Law." Cheyney, who continued the toughness in The Urgent Hangman (1938) and Don't Get Me Wrong (1939), apparently became very popular with the Armed Forces and prisoners of war.

But the near-conclusion to Orwell's Coming Up for Air (1939) was a long moan by the narrator about the inevitable coming of fascist horrors to Britain.

It's all going to happen. All the things you've got at the back of your mind, the things you're terrified of, the things that you tell yourself are just a nightmare, or only happen in foreign countries. The bombs, the food-queues, the rubber truncheons, the barbed wire, the coloured shirts, the slogans, the enormous faces, the machineguns squirting out of bedroom windows. It's all going to happen. I know it-at any rate I knew it then. There's no escape. (VII: 238)

\section{XVI}

that were legally available in Britain, was pervaded by sex-the most sexual English novel since Lady Chatterley's Lover, and a welcome change from the boy-girl persiflage in British movies.

\section{$148 \quad$ XVII}


obviously knew them. An episode from Lady in the Morgue is transposed practically whole into No Orchids, and the incident of the good guy stamping on the face of a prostrate bad one that Orwell complained about is straight from Bill Crane in Latimer's earlier and inferior Murder in the Madhouse (1935), where "There was a cracking sound, and under his heel it felt juicy." (Ch.XII, 191)

Latimer's three hard-drinking detectives in the off-stage Colonel Black's New York agency, about whose backgrounds we know virtually nothing, are the classic chivalric trio that began with Dumas and included the crusading American editorial team of Collier's and the three principal figures of the radical Masses (1911-1917). Crane, pretty obviously, is a college man, and tall handsome Tom O'Malley has an easy Irish selfassurance, both of them without problems as to which silvernware to use at table. All three (Williams obviously didn't go to college) are at ease with one another, with plenty of casual wit, and there's no difficulty with Crane's being the senior operative.

But Crane comes close to having a thumb-nail ripped out by gangsters in Lady in the Morgue, and allows a couple of Union thugs, in Headed for a Hearse, to torture an Italian café-owner (screaming hoarsely) who's withholding possibly vital information in a case. And the two final chapters of The Dead Don't Care, in which Crane and rich young Camelia Essex's boy friend Tony are captives aboard a cabin-cruiser off the Florida Keys in which Camelia is the captive of four gangsters, a couple of whom are all set to rape her before killing her, must be just about the finest stretch of narrative prose in any American thriller.

In chapter VI, there is some uncommon realism:

[Crane] wondered what it was like to be a woman and held by kidnapers. He often wondered what it was like to be a woman, but never before in connection with kidnapings. He supposed it was pretty bad. In the first place, when you were kidnaped, man or woman, you were always in doubt whether your captors would ultimately kill you or release you. But with a woman there was another consideration. With a pretty girl like Camelia Essex, especially, there was another consideration.

It was funny people never spoke about this. It was like solo transatlantic flyers. You never heard how they went to the bathroom, It was just something you never spoke about. And so was being raped by kidnapers. What was standard procedure? He was a detective, but he didn't know. How the hell could you know? A girl wouldn't say: Why, yes thank you, I was raped. He didn't think the average kidnaper was above a little rape. (80)

The British edition of The Dead Don't Care was published by Methuen in January 1938. Raymond, as we have been told, wrote No Orchids in the late summer of that year. It seems to me more and more likely that the grain of literary sand for him was The Dead Don't Care.

Horace McCoy's No Pockets in a Shroud, published in America and England in 1937, contains the following passage, spoken by the hero to a corrupt power-figure:

Well, the coppers don't particularly care for private dicks at best, so we took this fellow to a little room down in the basement. A sound-proof room, Senator, with only one chair-a replica of the electric chair-in the middle, with a big spotlight shining in the face of whoever sits in it. We strapped this fellow in and bruised him up a little, but still he wouldn't talk. So we went to work on him with the rubber hose-and a couple of hours later he admitted that Fred Coughlin had hired him. (ch 2, 96)

There is a character in the novel called Grissom. 
In a curious book of Jungian criticism, Persephone; a Study of Two Worlds (1952), D. Streatfield finds an archetypal Proserpine/Dis pattern in No Orchids. To judge from the enduring popularity of its basic narrative-two films, two plays, numerous reprintings by different houses-he might be onto something

In any event, No Orchids, with its fundamental task of rescuing the kidnaped Miss Blandish from her captivity, and the necessary third-degreeing of tough Eddie in order to find out where she is, fits in well with Orwell's paragraph about wartime ends and means that I quoted earlier.

In the same year, Geoffrey Household (who along with Michael Gilbert was the best of the post-Buchan thriller-writers) produced in Rogue Male an upper-class big-game hunter out to avenge the torture killing of his Polish lover by taking out with a long gun the Fuehrer himself, which would have saved the world a great deal of misery.

Two years later, in Latimer's Solomon's Vineyard (first published in England because too risque for the States), a tough fat private eye moves in on a corrupt community dominated by a quasi-religious, leader-centered cult, a predatory business man posing as the embodiment of traditional virtue, and an unabashed gangster, and cleans it up by means as extra-legal as those employed by Hammett's Op in Red Harvest, including giving the gangster a beating of what Orwell would reasonably have considered "unheard of brutality." ("I kicked his head a few times, but it wasn't worth while. He was out cold.")

After the war, in A Time to Kill (1951), a particularly sympathetic hero of Household's twists out of its socket the arm of a man from whom he desperately needs to learn where his kidnapped young son is being held in preparation for being spirited away to Russia.

\section{Part 2}

\section{J.F.}

\section{XVIII}

I propose now to do some filling in from my own experiences in the Thirties and Forties before returning to the Junglies from a different direction. This is not just because of the questionable pleasures of Memory Lane.

The model in Hoggart's indictment of those post-war novels, as in various indictments by others of the reading or viewing of the lower orders ("Is it a book you would wish your ... servants to read?" the chief Prosecutor at the Lady Chatterley Trial in 1967 famously demanded of the jury) is the familiar one of the introduction of toxins into a more or less healthy body, and, as with addictive mind-altering substances, weakening controls and creating mindless enjoyments and desires.

In the later nineteenth century, the sought suppression of the erotica funneled through Holywell Street, off the Strand, was driven partly by the thought of newly literate working-class youths, in the grip of inflamed passions, getting girls pregnant or picking up social diseases, and partly by the schoolmasterly dread of masturbation and the weakening of bodily energies and moral fibre. Like the opium smoker, the chronic masturbator would be off in a hedonistic trance that worked against the demands of an 
increasingly industrializing and imperialist nation. This attitude, with its stimulus/ response model, would persist well into the twentieth century.

Pollutants like La Vie Parisienne and Continental erotica more generally, including Ulysses and Lady Chatterley, could be held at bay by the vigilance of customs officers facing the English Channel in a "They shall not pass" spirit. And the British Board of Film Censors would do yeoman service with respect to movies and scenes of the "wrong" kind. But the imagination, as was apparent with pre-Code Hollywood movies, needed only a few glimpses of normally concealed flesh to feed it.

So when Darcy Glinto's Lady-Don't Turn Over, along with his Road Floozie (1941) and James Hadley Chase's Miss Callaghan Comes to Grief (1941), was under indictment at the Old Bailey in 1942, among the offending passages that were cited, and removed in reprintings, was the moment when Clare Holding, in a reprise of Miss Blandish's introduction into the Grisson lair, is socked on the chin by gang-boss Dill slitson and slams against the wall.

Then she slithered to the floor. On the way her skirt hooked over the corner of a chair and peeled itself back into a roll at her waist.

"Pretty!" sniggered Min. She meant the long stretch of silk-clad legs and delicate almost transparent knickers and the exposed white body from waistband up. (Ch.I, 18-19, italics mine)

The basic iconography of a lot of Junglie covers is there, and with it, if you simply looked at the covers without venturing inside, all manner of other exposures, and their stimulus-response provocations. The post-War British covers were sexier than American ones, and for a lot of collectors now, the Jungle is probably coterminous with the art of Reginald Heade, whose luscious images are likely to have no narrative connection with the contents. See the Web.

Glimpsing stocking-tops would be a hallmark of Hank Janson as a character.

\section{XIX}

171 However, the model of "mindless" enjoyment seems to me basically wrong. It wasn't simply a fascination with rape that had caused lots of the decent citizenry to buy lots and lots of copies of No Orchids, and attend performances of the play with so little sense of doing something discreditable that Orwell had to try and force a recognition of it in 1944, thereby ensuring Chase's novel and the genre a permanence that they wouldn't otherwise have enjoyed.

Nor was it an endless quest for more-more-MORE of the taboo that kept the lower orders buying and swapping those post-war paperbacks.

But before returning to the Jungle, I want to offer a very different account of the "reception" of influences in the Thirties and Forties by a sample audience that I happen to be well acquainted with, namely myself. And when I speak here and there along the way of "portals," I have something particular in mind.

174 XX

Portals, particularly those opening up into zones of danger, could provide an escape from Wallace Stevens' "malady of the quotidian" and the Hardyesque pessimism (related to Continental Naturalism) about hubristically ascending and bettering oneself, with sexual relationship especially problematic and doomed.

176 An obvious escape route, of course, was by way of chivalric romanticism, with the heroic knight, cowboy, police officer, ship's captain triumphing and winning The Girl. 
The trouble with that, though, was that after a while the persisting gap between one's models and oneself (as exemplified in Edwin Arlington Robinson's "Miniver Cheevy") could become bothersome. Their activities normally issued from the bosom of organizations into which it was necessary to fit-the armed forces, Scotland Yard, the ranch, and so forth-and what they accomplished depended on their being so focused and consistent themselves that they never lost self-control. Which are not frequent characteristics of the young.

Portals, on the other hand, as the Surrealists recognized in their dealings with cinema, could open up into dramatic spaces that were not socially organized, or were organized weirdly, so that one could escape from the moral clutches of the collectivity into the marvellous, the strange, l'insolite, where there were no hierarchies, a state that Orwell himself had enjoyed in those older American works with free spirits in them, and which he celebrated in the then quintessential anti-Establishment and sexual-boundaryignoring American, Henry Miller.

The following account of my own Americanization has had to be given at some length to bring out the complexities of cultural osmosis and assimilation-and also provide a space under the lights for a milieu that hasn't figured much in the broader narrative of democratization.

Ezra Pound, that prince of extra-curricular educators, opened his ABC of Reading (1934) with, "There is a longish dull stretch shortly after the beginning of the book." (xi). In the same spirit, anyone wanting to skip to the Jungle section will find it beginning in section XXXII.

180 XXI

181 George Orwell, as he explained in The Road to Wigan Pier (1937), chapter 9, was a member of the Empire-connected lower-upper-middle-class, and Eric Blair wouldn't have been a social anomaly at Eton, despite the dwindling of imperial prestige. In fact he seems to have done swimmingly there.

182 My own family-middle-, not upper-middle class-wasn't involved in the decline of Empire or of anything else. It was what I think of as service-middle-class, not in the martial sense, but because, whether you were doctor, or lawyer, or teacher, or civil servant, or (a first-cousin in the Marines) professional soldier, or (an uncle) interior decorator, or (a distant cousin) master-printer, you believed that what you were doing was of service to the community, and that you didn't lie to clients or customers or take them for all that you could get.

As I've said, I knew nothing first-hand about the older working-class culture celebrated by Hoggart, or even its deteriorated form. Nor do I know how typical all the elements of my own professional-middle-class boyhood in the Thirties were. The boys at my two prep schools didn't talk about their families. But we all seemed to fit together well enough, and my experiences, so different from Orwell's, not to speak of Hoggart's, may have something to show about cultural osmosis and assimilation. The "American" was a welcome presence from early on in my own kind of Englishness.

184 I myself, born in 1928, was a kid in the Thirties in a suburb on the northern rim of London, from which you could still get out among fields on your bike.

185 My father's father, by the sound of it, was the ideal general practitioner, Edinburghtrained, who never lost a mother in childbirth, put the fear of God into a couple of tyrannical big farmers whose labourers lived in "tied" cottages (lose your job, lose your 
home), with leaky cesspits beside the wells, and saved my mother's life when she almost died after giving birth to me in a London nursing home. And my much-loved grandmother was loving-care itself.

My father (born in their Wiltshire village in 1898) went to a grammar school in a nearby market town with a progressive headmaster and won a Classical scholarship to Magdalen College, Oxford, which he took up after the War. If any other members of the family had gone to university, I never heard about it.

As a second-lieutenant, he'd been wounded in 1918 in the open phase of the fighting, during which, being a good rifle shot, he most likely did some killing. Apparently he'd tried to get into the Royal Flying Corps, which wasn't the best of recipes for longevity in the days of Richthofen's Flying Circus, but had been turned down because of his eyesight.

He didn't talk about the war, apart from saying that being shot through the tummy was like being hit by a half-brick.

Switching to Law after his first year, he became a junior solicitor in the office of a couple of uncles, until in 1937 he was made a small-claims-court judge (County Court Registrar), with gown and wig, in which capacity he was protective towards the underdog (little old Jewish lady vs. grasping landlord). Bullying for him was a cardinal sin.

After the war, in which he had patrolled the night streets of Whitechapel and Bethnal Green as a Special Constable during the Blitz, he served for a number of years as Secretary of his professional association, became its President, and received a CBE at the Palace on his retirement. (The Beatles were mere MBEs, two steps down).

He was a member of the elite City of London institution Armoury House, headquarters of the Honourable Artillery Company, in whose company of Pikemen he marched on ceremonial occasions and stood decorative guard at Lord Mayors' banquets in the Guildhall, where he saw numerous notables from close to. On a very rare visit to Armoury House in 1951, I passed Churchill's military conscience General Lord Alanbrooke limping down the stairs and looking very bad tempered.

My father was a gentleman, a very effective gentleman, like others of his serviceoriented class, of whose existence American intellectuals dismissing as outmoded the concept of honour appear blankly ignorant. G.K. Chesterton was his favorite social commentator (he himself was Church of England), but he didn't share the Chestertons' and Hilaire Belloc's antisemitism. He never preached at me, and I'm sure he never used the word "honour" and its cognates, nor was I ever punished by him, and he was scrupulous about not invading my private spaces.

But he was utterly incapable of lying, cheating, or stealing, and he had a contained temper that an arrogant offender wouldn't have wanted to arouse. We had an aristocratic black Chow called Chang, and there was a sawed-off walking stick that my father had broken (I was told) on the back of an Airedale that was attacking Chang in the park.

He wrote doggerel Latin verse to entertain a friend or two, knew a lot about Roman Britain, and enjoyed tracing what he called "old dead railways." A walk with him in the country or at the seaside before the War was always a treat.

He also enjoyed thrillers. 
I'd had the A.A. Milne books, of course, and The Wind in the Willows (pretty noxious below its surface charm), and the Just So Stories, and the Jungle Books, and King Solomon's Mines and Allan Quatermain, and the three best of E. Nesbit's magic books, and Arthur Ransome's We Didn't Mean to Go to Sea (1937).

But among the books in the narrow drawing room, as I discovered at age nine, were Sapper's The Black Gang (1922, and much the best of the Drummonds), and Francis Beeding's The Six Proud Walkers (1928), in which a failed assassin's skin is stripped from his hand like a glove (an actual practice of the Bolshevik Cheka), and The League of Discontent (1930), in which the two heroes come upon a cache of some very curious drawings (undescribed) by Felicien Rops, and Edgar Wallace's The Door with Seven Locks (1926), with a couple of episodes in it that terrified me.

199 I also had books from my father's childhood, among them Andrew Lang's The Violet Fairy Book (1901),with its brilliant, scary, exotic Arthur Rackham-type illustrations, and a Chums annual from around 1911, three of the illustrations in which imprinted themselves permanently on my mind.

A youth armed only with a large knife rears desperately backwards amid the pythonthick tentacles of an octopus in a vegetation-fringed rocky pool. A youth on a rock in the ocean waves desperately towards a distant ship, with a comrade unconscious at his feet and sharks' fins circling. And a youth on the curve of a cupola (one of those on St. Paul's?), with a street far below, reaches desperately towards a jacket extended to him by a youth grasping a balustrade.

201 You can't do much better than those in the way of primal fears.

202 The novel The Rovers of Black Island, with the octopus and three sets of pirates, also figured in Graham Greene's boyhood reading, to judge from his reference in A Sort of Life (ch.2) to "a fine pirate serial which rivaled Treasure Island-by what forgotten author?"

203 In my grandparents' rambling house in a Wiltshire village, to which we went for Christmases, there was a set of bound volumes of the Strand Magazine, containing Conan Doyle's The Lost World serialized, with its prodigious illustrations (1912), and his "The Terror of Blue John Gap," in which a gigantic bear-like creature rears up by lanternlight over a holiday visitor to the Peak District who had imprudently tracked it down into its lair.

The world of my father's boyhood reading had evidently been a good deal different from that of the Magnet and Gem, which I can't imagine his enjoying.

As a grown-up, he loved M.R. James, whose Ghost Stories of an Antiquary (1904) were also in the drawing-room.

So much for the "Orwellian" side of my family.

\section{XXIII}

My mother, who had been a secretary in his uncles' office, was eight years younger than my father, and her own father was a commercial traveller for a major London fabric house, which I don't think my father's two sisters ever quite got over.

Since he and my other grandmother, as I was told later, literally never spoke to one another, my only contact with that side of the family was when Grandad came to us from Blackheath from time to time for a Sunday lunch, a comfortable old gentleman 
(well, old to me) who showed me tricks with fingers, and the sticky labels off banans, and a piece of string, explained how to fill out a football pool, and taught me the quatrain

$$
\begin{aligned}
& \text { Taffy was a Welshman,// Taffy was a thief, } \\
& \text { Taffy came to my house// and stole a leg of beef. } \\
& \text { I went to Taffy's house, // Taffy was in bed, } \\
& \text { I picked up the marrow bone //and hit him on the head. }
\end{aligned}
$$

210 Which was interestingly different from Horatius keeping the bridge and the boy standing on the burning deck. Poetry is where you find it.

211 Nor did I ever learn that I was half Cornish, in contrast to a lot of guff about Frasers from those aunts, which had me into a wee kiltie (though alas with no dirk) around age seven, and gave me a fondness for Bonnie Prince Charlie and other gallant losers, and the Pipes. As my father pointed out, he himself was only one-sixteenth part Scottish, making me one-thirty-second part. But it made no difference, family-wise. I was "Scottish," and not unhappy to acquire honorary roots. All that I knew about the paternal side of the family otherwise was that there had been a gasworks in it, near Brighton.

My mother, youthful, eager, curious, with excellent taste in clothes (earth hues plus touches of Art Deco), loved going up to Town to shop and take in movie matinees (she saw Top Hat three times), and went from time to time with my father to foreignlanguage movies at the Everyman, Hampstead, and saw Frankenstein together.

When she took me shopping, I might be treated to a milk-shake (novelties then), or hot roasted salted peanuts at Woolworth's, and we had Kraft and Heinz products on our table. When King Kong turned up at our local cinema, she tried in vain to talk me in past its rating of $\mathrm{H}$ for Horror, meaningabsolutely no-one under sixteen admitted.

214 She was responsible, I imagine, for the presence on the drawing-room shelves of Switch on the Light (1928), one of a series of anthologies by Christine Campbell Thomson, and including stories from the ultra-weird Yank Mag Weird Tales, among them H.P. Lovecraft's "The Rats in the Walls" and a terrifying Hands-of-Orlac story about a young man whose hands throttle his wife and ultimately, while he's asleep, himself. Plus an unfunny Little-Shop-of-Horrors plant in the conservatory of a mysterious doctor:

The trunk, which could be seen between the movements of the horrible limbs, resembled green marble; at the base it was as thick as a man's body, and increased in girth till, at a height of twelve or thirteen feet from the ground, it branched out into a hundred long, hairy boughs, all slowly moving as though alive. At the end of each bough, thick as an athlete's arm, was a sort of flexible funnel which evidently possessed the power of laying hold of objects and clinging to them so that there was no escape. The shortest of these boughs was seven or eight yards [sic] long. (169)

Portals!

216 Of course I never talked about them with anyone. I never talked with grown-ups about anything that I read. I'm glad not to have had their discourse invading my mind and interfering with emerging structures of feeling and the discourse in the books themselves.

217 My mother was probably responsible too for my having Erich Kästner's anti-Hitler allegory Emil and the Detectives (1929), not that I knew it had a hidden dimension. She also, I found, had typed out and put into an album some of Harry Graham's Ruthless Rhymes for Heartless Homes (1899), which amused me greatly. 
Eating more than he was able,

John fell dead at the breakfast table.

"Mummy dear," said sister Meg,

"May I have Johnny's other egg?"

219 I never had any sense that my father was uncomfortable with any of this. I don't recall any anti-Americanism on his part, apart from one or two allusions to lynching. John K. Blenkiron, Buchan's "good” American in Greenmantle, was a particular favorite of his, and among my nursery books was his boyhood copy of Fennimore Cooper's The Deerslayer, in which the brutal Hutter is discovered scalped.

I was never aware of any parental tensions. I don't think there were any. Not then. Not until the War.

On the wall of my parents' bedroom was a framed reproduction of what I've recently discovered was Rogier van der Weyden's “Adoration of the Magi." On my own wall, bought by my mother for me, were three Indians on ponies looking out across a sunlit valley to the distant white waggons of settlers.

She also helped me to get by heart, aged six, all seventeen stanzas of Southey's balladtype "Inchcape Rock," and inflict it on company. "Down sank the Bell with a gurgling sound/ The bubbles rose and burst around," etc.

\section{O.P.P.S.}

\section{XXIV}

After three years in a kindergarten run by a formidable maiden lady in which I made a plaster-of-Paris map of Africa (drawn, not traced), compiled a scrapbook about New Zealand, chanted part of Kipling's "Land of our birth, we pledge to thee," plaited raffia, went on nature walks, and read a condensed version of Hiawatha, with some rather creepy goings-on in it, I went to a day school in a nearby suburb, Oakleigh Park Preparatory School, that was very different from Orwell's Crossgates.

The boys would mostly have been the sons of professional men, I imagine, but we never talked about families. We had unostentatious school uniforms-grey-flannel jackets and shorts, with pale-blue caps-and did all the usual schoolboy things-cricket, soccer, gym once a week, a sports day, some boxing lessons, conkers in season. But sports weren't fetishized, and though we were nominally in different "houses" at the weekly gym sessions in a nearby suburb, run by a retired sergeant-major, there was no serious attempt to drum up group spirit. Writing lines was the normal punishment, and a caning by the Headmaster a rare exception.

The school crest was Pegasus, with "Per Ardua ad Astra" under it. But the Head never suggested that we live up to it, or talked about our future prospects. Nor did my parents.

227 At lunch in a room with four long tables that otherwise served for lessons, and with a master at each end, what we largely talked about were movies and radio programmes. No doubt there was some interest in professional sports, but I've no recollection of it. I missed out on programmes like In Town Tonight and Monday Night at Eight, and serial thrillers like The Mystery of the Mine, because of having to go to bed early, with my little 
supper and something to read. The most English medium, as it would continue to be, was the radio.

The movies included ones that we couldn't all get to see because of the classifications, such as The Son of Frankenstein (1939) and The Black Cat (1934), about the latter of which one of the young masters, as I learned later, lied inventively when begged for a description of how someone was skinned alive. Another chose for dictation a passage from the $16^{\text {th }}-17^{\text {th }}$ century A Hangman's Diary beginning, "The beheading sword was a heavy two-handed weapon, the proper use of which required great skill and strength." They knew their audience.

The Tower of London, with Boris Karloff, and a torture episode in Lives of a Bengal Lancer, neither of which movies I saw, also came up at lunch. Pain back then was more stimulating than sex for pre-pubescents. (You could give one another a Chinese Burn by twisting your hands in opposite directions on their wrist.) On one occasion a heavy rubber-truncheon, presumably from Germany, was passed around the lunch table.

There was no American-type machismo, but a boy who went home for lunch and was a bit odd physically was swarmed on the playground, and a redhead was occasionally provoked into rage. Two tough Jewish boys from the Continent joined the school in 1938 , and at least a couple of other boys were Jewish, but I don't recall the word "Jew" ever coming up.

The pedagogy was stone-age, but at the end of the summer term in 1939 I won a Graillike cup by reciting, in an annual competition, an assigned passage from Tennyson's Idylls of the King about Arthur's "last dim weird battle in the west" with the forces of Modred. It had been chosen by the headmaster's wife with what I came later to realize must have been allegorical intent.

\section{$232 \mathbf{X X V}$}

Memory does play its tricks, though.

When I embarked on this time-tripping, I expected to be saying simply that the movies that we watched back then were predominantly American. And so, at least where I was concerned, they were, particularly in 1937-39, when you lurked outside the theatre with your sixpence until some friendly adult would take you in to an "A" movie. But they weren't American in quite in the way that I'd remembered.

The British movies that I became aware of through previews and schoolboy chat were mainly comedies-"popular" ones with Will Hays, like Oh. Mr. Porter! (1937); classier ones like Bulldog Jack (1935) with Jack and Claude Hulbert as amiable upper-class chappies who stumbled into danger and lucked out.

But the biggest block of movies were romantic-chivalric American ones with heroes who, whether or not played by actual British actors, often embodied ideal British energy and grace better than in actual English productions-movies like The Dawn Patrol (1938), The Prince and the Pauper (1937), and Captain Blood (1936), along with a few British ones with the same qualities, such as Sanders of the River (1935) and King Solomon's Mines (1936), the latter spoiled by having a girl in it.

There were some prestige and/or "serious" movies like Pygmalion (1938), and Things to Come (1936), and a few thrillers like The 39 Steps (1935; a girl again, not there in the book) and The Lady Vanishes (1938), and at least one depressing movie with gangsters in it, Dead End (1936). But they didn't cohere, and I never did get in to see an " $\mathrm{H}$ " movie. 
And there were American portals, or what would become portals in memory.

In a circus movie, with the effect repeated three times, a wall of barrels and boxes trembled and then came crashing down (this was at night, under arc lights) as a gorilla pushed terrifyingly through it and came towards you-towards you.

A pea-jacketed seamen stumbled his way around a misty deck, lone survivor in The Mystery of the Marie Celeste (1935), that name so redolent of the uncanny-a schooner found inexplicably abandoned, with the stove still warm and the crew never found. In The General Died at Dawn (1936), a Chinese warlord's men faced one another in two rows on the deck of his riverboat, in misty lighting, and shot one another to death (off camera) with their revolvers.

In a phantasmagoric nightscape of gleaming fast cars, and gangsters, and cops, seen around the age of five (my very first movie had been the Tarzanesque Caspar the Lion Man), the two halves of a dish were placed around a man's neck to give the impression of a severed head resting on a torso.

The unseen could be almost as thrilling as the seen, like the posters (greenish, as I recall) for the double bill of the re-released Frankenstein and Dracula in 1938.

The Revolt of the Zombies (1936) was wonderful in anticipation, but after announcing it as a coming attraction, with an "A" certificate, meaning that I could get in, the theatre decided that it wouldn't or couldn't or mustn't be shown.

A grown-up cousin who rented a room in our first house tormented me with a movie too horrible to be shown, made from a novel too horrible to be named, and which I wasn't permitted even a glimpse of. When he joined up and left a newspaper-wrapped package of books in our second house for safe keeping, the researcher's instinct awoke in me, and I extracted from it H.G. Wells' The Island of Doctor Moreau, plus Bram Stoker's Dracula.

Above all, there was the sublime Hounds of Zaroff (1932) (The Most Dangerous Game), to which my sister Deborah's part-time nannie was allowed to take me one night. When we entered the theatre, the most appalling screeching was coming from a pitch-black screen, making me feel that this time I was in over my head. But it was only a documentary about the depredations of foxes. The moment was still to come when Joel McCrea, sole survivor from those swirling sharks after the yacht foundered off-shore, struck the castle door hollowly, once, with the knocker with the wounded centaur on it, and after a pause the heavy door slowly swung inwards. ...

Years later, Les Chasses de Comte Zaroff would be the featured topic in the first number of the Surrealist-influenced French movie 'zine Positif, which led me to the great MidiMinuit Fantastique and Ado Kyrou's Le Surréalisme au cinéma.

What movies did Orwell see for pleasure, I wonder? He must have seen some. In the 1930s, cinemas were the only convenient places in which to do a bit of snogging. To judge from some wartime reviewing, in which he talked as if he'd been watching filmed plays, his tastes were conservative. In 1935, he went with his friend the cultural anthropologist Geoffrey Gorer to Anna Karenina, with Garbo, and found it "not too bad." (X, 399). In 1940 he enthusiastically reviewed The Great Dictator.

\section{XXVI}

The boys' weeklies that I bought at the newsagents-cum-tobacconist-sweet-shop near our school were principally the ones that Orwell hated-Champion, Hotspur, Wizard, Rover, Adventure. Orwell's preferred Gem and Magnet were there too, but for me, with 
their drab two-tone covers, they were profoundly depressing-a claustrophobic snobbish little world of Eton jackets, alien slang, no "action," and the grotesque Billy Bunter.

Why on earth would one choose to go there with one's weekly pennies when one could be in among Strang the Terrible fighting dinosaurs, Rockfist Rogan, R.A.F., up in dogfights, a serial in which a baddie tried to wreck a mining operation with the aid of an unstoppable radio-controlled steel robot called the Crusher, and another in which a baddie in Chicago, with future larceny in mind, kept a giant octopus in a swimmingpool in the unlit basement of a skyscraper, into which, in each episode, some unfortunate would descend for a midnight dip.

The Thirties were a time of bigger and better and faster machines, speed records broken, longer-distance flights, deep-sea divers in rubberized suits with those wonderful round brass helmets, blue-ribbon Atlantic liners, sports heroes, and newsreels showing war in Abyssinia, China, Spain, and Spain, with occasional glimpses of Nazi rallies.

We would have been baffled by Orwell's polemic against our comics. It would never have entered my mind that they promoted "bully-worship and the cult of violence." They were more about survival and achievement, especially (the categories are Orwell's) ones like Wild West, Frozen North, French Foreign Legion, and Great War.

As to their invitations to identify with a "G-man, Legionnaire, Tarzan figure, air ace, master spy, pugilist..." (69), one might as well extend the indictment to the whole canon of Western heroes. Nor was the hero "usually a sort of human gorilla." (70)

None of this instilled in me any hunger for martial action myself, and, as I have said, there was no machismo at Oakleigh Park. Insofar as conditioning was occurring, I would say that what it did was to make going into the armed forces, if and when called upon, a natural thing to do. Which, given the state of play in the later Thirties, was not an unreasonable or dysfunctional attitude. Rockfist Rogan, having begun life in the Royal Flying Corps, went on to become a Spitfire pilot.

249 Curiously the cowboys and lumberjacks stories were the ones that I liked least, nor did I particularly enjoy movie Westerns like The Plainsman (1936)and Union Pacific (1939), let alone a girly one like The Cowboy and the Lady (1938).

CuriousIy, too, I cannot summon up any images of Yank Mags in that newsagent's or on the counters in Woolworth's, apart from the issue of The Octopus that I bought at the newsagent's in 1939 because of the tentacled character on the cover, plus on another occasion a Spider 'zine. Maybe the angry guys in dark suits and soft hats on the covers of toughies, socking one another with fists and blackjacks, or blasting away with heavy automatics, were too alien for me.

And the human monsters on the covers of shudder pulps would have been too grotesque, as were the figures in some American Sunday funnies that I was able to look at one day on a country family's littered floor-Terry and the Pirates, Little Orphan Annie, etc-and actors like W.C Fields and the bumptious Mickey Rooney (not in fact Irish), who was every decent English schoolboy's idea of what a boy shouldn't be. Nor did I go to kid's matinees, with their horrible singing cowboys.

I also never bought, or recall seeing, a copy of that still today a bit mysterious tabloidsize weekly The Thriller, begun in 1929, with a fresh novel or novelette in each issue by writers like Edgar Wallace, Leslie Charteris, Bruce Graeme, John G. Brandon, Hugh 
Clevely, Stacey Blake, L.C. Douthwaite, Gerald Fairlie, Sydney Horler, and dramatic illustrations. I don't know what its target audience was.

The Thirties had been a comfortable time for me, particularly after my father was appointed to the bench and we moved a few streets away to a substantial semidetached house with two attics (one of them dark), three cellar areas (more darkness), a pit under boards in the garage, and, in addition to the normal garden with its fruit trees, an allotment stretching alongside the railway line, containing a mysterious low shed built of railroad ties with a cage-like front. There was a rumour that the previous owners, who had turned the lawn into a badminton court, and left behind a large wooden aeroplane propellor, had kept a python. But the bars seemed a bit far apart for that.

Our live-in cook-maid from Newcastle, her father a coal-miner, moved with us from the small previous house. And each summer there was a three-week seaside holiday, with some piers with penny-in-the slot machines, and a couple of castles, one of them (Pevensey) with a newly discovered oubliette, and, at home, family trips to the Zoo, and the War Museum, and the Natural History Museum, and the Science Museum.

Words like "Depression" and "Slump" meant nothing to me. The nearest that I came to any contact with the poor was when around age seven I stayed for a week at a house in the country in which my High-Church godmother provided slum kids with a month of clean clothes and decent food, and a girl a little younger than me introduced me to another zone of poetry with the first two lines of a song that went, so far as I could make out, "I could ride a sarnet/ Upon an ease to Barnet."

When I asked what it meant, she looked knowing. Another portal.

\section{Wellow Wood}

\section{XXVII}

When the war came, O.P.P.S closed, and two of the younger masters bought a small boarding school down in Hampshire, near Romsey, out in the country. It was essenceof-boys'-school, with all the nice things and none of the nasty- football and cricket fields, a charming little whitewashed chapel, dormitory romps, drawing and music lessons, crocodile walks and talks, no bullying, no prefects, one mild honour-bestowing caning by the Head, half-term outings, a nice school song about Hampshire, visits to Winchester Cathedral and Beaulieu Abbey, sing-songs around the piano including "A Hundred Pipers" and "The Vicar of Bray," an English master who made the subject fun, and a school library that included Anthony Armstrong's hilarious tales about Pilotofficer Prune and others.

Total Englishness, even if not Hoggart's.

My parents were a bit disconcerted, though, to discover at home a little story that I'd written in an exercise book in which rescue did not come before the hanging, drawing, and quartering took place. (Fortunately I'd got the meaning of "drawing" wrong.) My explanation-the question was raised on a half-term-holiday outing-evidently reassured them that I didn't require professional attention, and I got them to take me to a Thin Man movie. But Poe's Tales of Mystery and Imagination, tackled in the sickroom, were strange and depressing. 
Forced to evacuate in a hurry in the spring of 1940, we were shipped up north on a long days' journey to the utterly alien Westmoreland, with its abrupt bare little hills, serpentine lanes, fast-flowing cold streams over pebbles, and dry-stone walls. A girl was added, someone's big sister, Bunty Barwise, who confidently drew high-style women's shoes (wedgies, high heels) and streamlined planes and cars.

One day, exploring in the loft over the stables, I came upon a pile of Yank Mags, probably cleaned out from the room of the son of the house, now in the Forces, in preparation for our coming. Among them were what must have been ones like Horror Stories, Terror Tales, and Dime Mystery from the infamous late Thirties.

A gang member who had angered his boss had his hand strapped to a board and wedges tapped in under his finger nails. A girl was given the strappado, with the help of a winch, her last fall so extreme that her arms were ripped from her body. There was a drawing of her up there before that happened.

I was eleven, going on twelve.

The previous August, 1939, in a seaside boarding house, there was another portal-a French weekly containing several photos of a Grand Guignol production in which a blind man gouged out one of another man's eyes. What did "Guignol" mean?

And at some point I'd gone to Madame Tussauds, with its unreal- looking royalty, and sports aces, and movie stars-public figures all, from the bright lights-and descended into the only part that mattered, the darkened Chamber of Horrors with its coiners, and poisoners, and burglars, dark figures who had sought obscurity while alive, and become defined, some of them, by a single irrevocable deed, and whose actual implements on display, along with fetters and instruments of punishment, had a reality absent up top, even in the one or two execution tableaux. Behind a curtain a life-sized figure, blood glistening, dangled from a hook driven through her waist.

Wellow Wood went out of business in the summer of 1940, and everything changed for the worse-much worse.

\section{The School}

\section{XXVIII}

Take one large two-story day-school on the edge of a market town fifty miles west of London. Attach to it a boarding unit for some fifty boys. Supply that with a generalpurpose dining-room/prep room/hobbies room, plus a small common-room largely occupied by a scaled-down billiard table onto which a ping-pong table could be put, plus a changing room in which to take cold showers on getting up. Plus a school library with a large reproduction on the wall (Bouguereau?) of a near-naked Orpheus with dead nude Eurydice at his feet.

Have each dormitory room contain about eight beds, uncurtained. Turn off the heat at night, provide too few thin blankets, and insist on the windows being kept open during the winter. Have a less than competent cook cope with wartime rations, cheap gristly cuts of meat, occasional powdered eggs, oatmeal forming lumps in watery porridge. Add black school jackets with shiny elbows, and grey flannel trousers that weren't replaced to match one's growth (clothes were rationed), and heavily darned wool socks that shrunk so that the heels were below one's soles. Plus an incompetent tweaking barber who visited every few weeks to give short haircuts, British style. 
Have the boys turn out in thin rugger shirts five times a week for games or practice. Have an annual cross-country run in the winter-twenty-five miles for the bigger boys, five for junior ones, without any training. (A new master with a university half-blue in running got all that changed before I had to do the senior one.) Require permission to go down town. No girls, of course. They remained distant Ronald-Searle-like beings in their school uniforms several blocks away. None was ever on the school grounds that I can remember, nor were there any individual contacts that I ever heard of.

oh, and have the sirens go off every few nights, and everyone troop down to try and sleep on paillasses stuffed with straw in overheated airless corridors. However, no bombs ever fell, though once a Heinkel with the black crosses on its wings, zoomed overhead on a sports-day, the rear-gunner fortunately dead, or so we were told later.

\section{XXIX}

Yet this wasn't the hell of conventional "protest" recollections of English public schools.

There was no bullying, except for one slightly retarded dayboy. Prefects up in their tower room over the main building didn't have fags in the British sense. Only the Head could cane, and did it seldom, no boarder ever being caned during my time there. During the first couple of years there were several exceptional senior boys, heroes on the rugger field, keeping order at school assembly by their mere patrolling presence, true officer material without any affectations.

The compulsory turn-outs for rugger in all weathers, in addition to lessening (presumably) our sex drives, were probably war-oriented, but no big deal was made of our occasional Cadet Corps activities, and I wasn't picked on for being no good at games and hopeless in the gym.

Later on, a few of the London boys, three of them Jewish, including a couple of hardcore Marxist-Leninists with the latest figures for steel production in Kiev at their finger-tips, took their places. I and John Lynes, nowadays an undeflectable peace activist, belonged to Richard Acland's quasi-syndicalist Common Wealth party, which Orwell mentions sympathetically, so there were some "frank and comradely" arguments about ends and means.

279 This too wasn't Orwell's Crossgates. There was no class snobbery that I was aware of, and no privileging of better-off boys with their own tuck-boxes or even, so far as I know, cash. Not officially, anyway, allowances of a shilling or two or so being doled out once a week to each of us by the Head.

It was all a splendid education in scarcity and deprivation. (Would the dish with seconds on it be emptied before it got to you as it was passed down the table? Would the movie usher come out and announce to the queue that the theatre was now full, and that all of you beyond this point had no chance of getting in?). It was also an education in the clandestine-sneaking downtown to go to a movie on forbidden days; sneaking up to the prefects' room at night to listen to swing on the American Forces Network turned down low.

281 Lying under an eiderdown in my room at home with the electric fire on during the winter holidays, and knowing the unheated dorm that awaited me, gave me a mental taste of what it must have been like standing at roll call in pajama-thin striped uniforms in concentration camps with an east wind blowing through the wire. 

and when my father offered me the chance to transfer to a day school when we moved back to our London house after he re-married, I declined.

But I've never wished that I'd gone to a different school or had "inspiring" teachers, back to our London house after he re-maried, I declined.

\section{XXX}

This was a kind of Occupied Europe of the mind, and America and things American were instant liberation-jazz and swing on the American Forces Network, "In the Mood," Bing's effortless grace with "Moonlight Becomes You" and "Ain't Got a Dime to My Name," Bing and Bob and Dottie on the Road, Betty Grable, Alice Faye, Jinx Falkenburg, Ann Miller, Abbott and Costello, Leon Erroll, Blues in the Night, Stage Door Canteen, Harry James, Artie Shaw, Cagney in Yankee Doodle Dandy Tyrone Power in The Black Swan, Bogart in that desert movie, on and on, and all of it downtown fifteen minutes from the school gates. I don't recall seeing Casablanca, though.

It was romance. It was guys and girls. It was GIRLS. And the most marvellous love songs.

It was the smooth loose-cut tunics and comfortable-looking brown soft-leather boots of America soldiers in the street, compared with the coarse serge of our own cadet-corps uniforms, with their strap-on gaiters over the tops of beetle-crushers. Nor do I recall ever seeing Yanks behaving badly in town on Saturday, even though there was a large air-force base nearby. My guess is that they were pretty strictly monitored by their MPs when off base, whereas London was where guys went on leave. Once a couple of us crept up close at night to a marquee in a field from which swing was emanating. We didn't trip over couples or witness drunken fights in progress.

7 And I found a tuppeny lending library full of books like Edgar Rice Burroughs' John Carter on Mars series, and Albert Richard Wetjen's Shark Gotch series, and reminiscence about the horrors of life in the French Foreign Legion. The only Yanktype mags that came my way during the war, however, were a copy of Black Mask (not in the least scandalous) and Shark Gotch of the Islands.

8 In my North London suburb, to which we returned in 1943 after my father remarried, there were six movie theatres within easy distance, and what with two or three of them showing three sets of double features in a week, there were over twenty different movies, including plenty of B-movies, available in any one week during the vacations. With more options than before the war, and more to identify with.

9 Part of what had happened was that American heroes, whether or not in uniform, were now engaged in familiar activities-being soldiers, or secret agents, or spy-catchers, or pilots; finding ways around shortages; dodging over-zealous officials; coping with girls during 48-hour leaves. I can recall almost no gangster movies, apart from Kid Galahad (1937). I would guess that the images of America and Americans had been pretty carefully tailored once America was dragged into the war.

One way and another, I made the acquaintance of that galaxy of more or less Irish actors in the employ of Hollywood Jews with a deep understanding of America's fondness for chivalric qualities-Errol Flynn, Tyrone Power, Pat O'Brien, James Cagney, George Murphy, Joel McCrea, Lew Ayres, Spencer Tracy, Bing Crosby.

But there were still occasionally other dimensions, and episodes in a couple of sinisterhouse movies, The Cat and the Canary (1939) and Night Monster (1942), terrified me. 
In 1943, three of us at school came up with the idea of a jazz trio-clarinet, piano, drums-with myself on clarinet. Since I had and have no musical aptitude whatsoever, my lessons from a lady music teacher away from school were a mutual embarrassment. But the search for a used B-flat simple-system clarinet had me haunting the Charing Cross Road area, with its music shops, and store-windows displaying books about birth control and flagellation, and I yearned for Yank-style suits and jackets like those in the windows of Cecil Gee.

In the two years of the Sixth Form, when I started reading seriously for scholarship purposes, I discovered Ezra Pound's wonderfully liberating (American) How to Read, which made culture exciting, and I pretty well stopped reading thrillers of any kind, even during my two conscript years 1946-1947, which after the boarding school years felt like luxury. I also became fleetingly acquainted at Oxford with three actual Americans, one of them George Steiner.

Two major portals stayed with me from The School.

Lady-Don't Turn Over turned up amazingly in 1943 in an empty locker in the common room, without its covers, and with what appeared to be indeed a final page missing. (It had been circulating among two or three older boys.) What with Lynx Hanson fondling blindfolded society girl Doreen Milmay in the Chrysler Airflow, the flogging of Clare Holding with a rubber hose by hunchback Min, the stroking by Dill Slitson of the slits torn in her panties, the rape of blonde, soft, nice Edda Van Luys by Mouth Fennig, the third-degreeing of Hanson that goes way over the one in No Orchids, and the hara-kiri killing of naked stripper Cora Bilt by the Jap gangster Matsu, it was a heady mix.

And one half-term Sunday evening, the heavy-set and jocular-sinister senior math master showed Battleship Potemkin out of the blue to a few of us in his home, with its amazing close-up of the sabered bourgeoise and her shattered pince-nez. This was before I knew the hallucinatory Russian and German stills in Roger Manvell's Penguin Film (1944), so it came from out of nowhere. Which was the only significant intellectual input that I can recall from any of the masters, to my advantage. There was less to unlearn.

But the English master gave me my head preparing for scholarship exams, and I read lots of Elizabethan and Jacobean plays, 'Tis Pity She's a Whore, and so forth, in the old Mermaid editions. And though he was Oxford himself, we used in our Sixth Form discussion group a couple of Leavis-derived textbooks, one containing a fascinating portal from Joyce. In Paris in the summer of 1946, I would haunt bookstores in search of Ulysses, that secular Necronomicon, which the Headmaster, a bit imprudently perhaps, had called the filthiest book ever written.

In any event, even if I couldn't contrive to be from Yorkshire, I wasn't one of those snooty public school chaps, I was a Grammar School Boy. And despite ten years of it, I never acquired any Latin.

\section{Part 3}

\section{Jungle: Introduction}


Let me now offer a more sympathetic and I hope more accurate account of the Mushroom Jungle, that landscape of portals, than Hoggart's. This will entail some guesswork, and not just because of the inaccessibility of so many works.

My two years in the RAF, spent, after two months of basic training, as a clerk on a prewar Flying Training Squadron base in Norfolk, with well-built barracks and HQ, pretty well sealed me off from a lot of civilian discomfort in 1946-48. We were well-fed and well housed, with no needless discipline, plenty of freedom after hours, free travel passes, and pay.

The other clerks in HQ and in my barrack room with a dozen beds, would have been white-collar workers in civilian life. The talk in the HQ office was mostly about sports. (Those were the days when people argued the respective merits of Bradman and Hobbs in cricket.) And when I was moved into a barracks with aircraft mechanics, these were still members of a craft, and civil in their dealings with one another. No paperbacks circulated that I was aware of.

I remained pretty much in a bubble during my subsequent three years at Oxford, apart from a summer month of horrendous work in a steam laundry (later Colin Wilson did a stint there, I believe), where I didn't have the time or energy for chat. I never heard at home about the black market, which my father and stepmother wouldn't have dreamed of patronizing. I don't remember newspaper headlines about crime waves.

But I know enough about my own thought processes to be able to make some informed guesses about reading processes.

\section{XXXIII}

307 At the end of the war, a lot of still young men were demobbed into a Britain that was virtually bankrupted when America under Truman called in the loans made in the Lend-Lease programme begun while America was still officially neutral. It was an England of chronic shortages-food, clothing, housing, sex. Given the shortage of accommodation, a lot of the returnees had to either defer marriage or move in with parents. Unmarried sex wasn't all that easy. Where did you do it?

Entertainment was likely to be a weekend movie and a few pints at the local. Reading, if you wanted escape, was still cheap-it had been encouraged during the war-and people were still readers. But what would you read now if you were working-class?

The desire to escape and lose oneself in a narrative can be a hunger.

I myself knew and loved that experience, and had it with The Thirty-Nine Steps, Rogue Male, The White Company, The Lost World, The Invisible Man, Shark Gotch of the Islands, The Black Gang, The Rovers of Black Island, the Saint passim. Wittgenstein, according to Norman Malcolm's lovely little memoir, read Black Mask, and would sit up front in movie theatres, simply to have a large screen looming over him, the goings-on of which didn't greatly matter, just so that he could momentarily turn off his mind.

But for escape, you need congenial ideologies that are so much a part of the works, like water taken up into instant rice, that you don't have to think about or question them.

You don't want moments where you have to worry about whether this or that action is really the right one, any more than you want unfinished business left behind as though it were finished. When something's done, it's done. The carpet has to keep rolling up behind as it unrolls in front. What you're thinking about is the now and what may come. 
313 You don't want alien codes and traces in there-cultural allusions, turns of phrase, editorializing (political, ethical, religious, and so forth) that jerk you back out of the experience.

314 The working classes had long memories, and the Tories had learned nothing, and in the election of 1945, there was a major changing of the guard in Parliament, but not of social structures.

There was no major shift towards workers' control. Workers were not, en masse, reading blue Penguins, and Fabian Tracts, and the rest of it, with a sense of a realizable brave new world of the kind that Orwell wanted-and which figured for Richard Acland's Common Wealth party, to which I myself belonged for a bit. There were still the managers and the managed, the bosses and the bossed.

And guys were fed-up with having been bossed around in the Forces, whether or not in combat.

317 A number of works that I myself enjoyed, particularly in the chivalric tradition of Buchan and others, were essentially overclass. In my hunger for suspense and action, I had also been reading Green Penguin authors like John Dickson Carr (but not, emphatically not, Agatha Christie and Ngaio Marsh), and Four Square books, and White Circle books, with authors like Bruce Graeme, Sidney Horler, and John Creasey. But they too, particularly those written during the war, were still basically law-and-order ones, including Cheyney's.

It is a piquant thought that Orwell himself, when he was reading his Yank Mags in the Thirties, was probably escaping from, for him, the claustrophobia of the wrong kinds of Englishness, especially upper-middle-class Englishness.

And there was the question of pace.

In an interview, the actor who played the hitchhiker in The Texas Chain Saw Massacre, and who had done prison visiting, explained that attempts to calm convicts by showing them Disney features were getting things all wrong. Their body-rhythms, he said, were set much faster, so that the drag of stretches of narrative in which nothing "happens" was not just uninteresting but intolerable.

321 Boredom can be a pain, because, like when you're being talked at by a bore, you can't wholly switch off attention, yet none of the elements move in the direction that your mind tries to take them. When you don't find a joke funny it's not funny. When you're bored, you're bored.

Orwell was perplexed by the paradox of someone during the Blitz asking a newsagent for Action Stories. It seems to me, in contrast, eminently natural, since such narratives were strong enough to override, like sounds overriding pain, the clatter and chaos and fear.

\section{XXXIV}

Moreover, there was now a British culture of actual crime analogous to bootlegging during Prohibition, in which restricted desirables were "liberated." In her fascinating London 1945, Maureen Waller reports that:

When the Commissioner of Police at the Metropolitan wrote his annual report for Parliament for 1945, there was no masking the fact that crime was rampant and, worse, on the increase. London, as usual, was the crime capital of the country. Criminal gangs flourished, The Piccadilly Commandos and Hyde Park Rangersprostitutes in the West End-plied their trade with impunity, while their less 
professional sisters were not above luring some hapless American serviceman into a dark corner and robbing him. Looting of bomb sites, sometimes while the dead and injured lay trapped in the debris, was not uncommon. Pilfering from employers was rife. Robberies from warehouses and highjacking of lorries fed the black market, which was increasing in vigour as wartime scarcity continued into the peace. The damaged state of much of the property in the capital-and the absence of many householders in the country-made breaking and entering a cinch. There was a rash of female burglars. Deserters without papers roamed the street preying on the public to survive. Even respectable men and women were increasingly drawn into a dalliance with crime.

Furthermore,

War offered fresh opportunities for crime. Sleek in their Saville Row suits, their molls dripping with furs and jewels, London's underworld kings were having the time of their lives. But there was also a new breed of criminal abroad: ruthless young men, armed robbers, who meted out gratuitous violence with casual ease. Criminal associates such as the Elephant Boys of Bermondsey, who had robbed a City jeweller and run over a brave but foolhardy man who tried to stop them in December 1944, had no compunction in shooting to kill as they made off with their booty. Armed violence had been imported with the Americans, who lived in a society where guns were commonplace. By 1945 the country was awash with guns, illegally sold by American servicemen at $£ 25$ for a handgun or brought back by British servicemen from abroad. (242-3 Shark Gotch bools) camp, and whom I imagine my father knew at Armoury House, wrote excitingly about aspects of postwar London crime in thrillers like They Never Looked Inside (1947), The Doors Open (1949), and Fear to Tread (1953), with large-scale black-market and thievery operations, overclass master-minds, and ruthless enforcers. But the viewpoints were very much those of the Decent Citizenry, and, when pinch came to crunch, more disturbingly than in the late Twenties and early Thirties, efficient police and legal work prevailed.

\section{$328 \quad \mathbf{X X X V}$}

And there was the nature, too, of suspense and the thrilling. Thrillers are an affair of dangers faced, risks run, adversaries defeated or eluded. Thrillers need scary villains, as Lee Child has shown us in his riveting forays (man nailed to bedroom wall, wife fed his cut-off testicles) beyond the viciousness of John D. MacDonald's all-too-real-feeling creations like Boo Waxwell (Bright Orange for the Shroud), Junior Allen (The Deep Blue Goodbye), and Max Cady (Cape Fear).

With respect to the real-life capacity for evil and the deliberate infliction of pain, there had been large intensifications.

331 The full horrors of rotting or frozen corpses in WW1 trenches, and men drowning in shell holes, and the wounded crying out in No Man's Land, had been pushed out of mind after that war in the cleaned-up sound-stage simplifications of going over the top and through the wire to the rat-tat-tat of machine guns. They were more like natural catastrophes-shipwrecks, train wrecks, mine disasters. 

America.

There had been atrocities, in Belgium , and Serbia, and Armenia. But the Bryce Report of 1916, about German atrocities in Belgium in 1914 contained such unpleasant firsthand recollections that it probably had a lot fewer British readers than the Government would have preferred, though the primary audience would have been still-neutral

The centrality of torture in Nazi Germany had changed the game, starting with the settling of scores with Communists by the Brownshirts in 1933. Previously, in terms of popular imagery, torture was what was done by Red Indians, and the cruel Chinese, and the Spanish Inquisition, and the like. Truly atrocious things could now happen to decent people in the heart of modern Europe.

When Richard Hannay goes jaunting through wartime Germany in Buchan's Greenmantle (1916), he knows that the worst that will happen to him should he be detected would be to be shot at dawn, with a glass of cognac or schnapps and a final cigarette, Turkish of course. In Hitler's Europe in WW2, a spy, gentlemanly or not, would almost certainly have been tortured.

Orwell and his friend Arthur Koestler belonged to a generation for whom torture was all too real, not just a matter of (claimed) propaganda. When in Arthur Koestler's Arrival and Departure (1943) the hero is beaten on the buttocks during a Gestapo interrogation, "He heard himself burst into long savage screams, felt his bladder empty itself, his stomach turn and throw up its contents onto the table."

But in decent paperback fiction there were parameters, and pales not crossed, and magic shields, and details not given, and nick-of-time rescues.

It's not that there needs to be a string of atrocities, simply that an episode, probably early in the action, demonstrates the now thinkable, sayable, showable potentials for viciousness on the part of bad guys.

\section{$338 \quad$ XXXVI}

Moreover, other very different books would have been in circulation.

No Orchids, so popular during the Blitz according to Orwell, came out in 1939. And it had successors, especially during the time of the phony war, of which we learn in the ghostwritten memoirs of gangster Billy Hill that:

It seemed that London had got over the first shock of the war and had now adjusted itself to a new and strange existence. To a great extent the black-out and a depleted police force increased the opportunity for crime. So did the loose money which was flying about the country. The result was that the West End became a roaring square mile of bustling prosperity and activity. Women flocked from all over to walk the streets and haunt the hotel lobbies, bars and clubs. Good-time girls became brazen tarts, ordinary wives became good-time girls. Small-time tealeaves turned into well-to-do operators. In the netherworld of pubs and clubs, of spielers [gambling dens] and dumps, you were assessed by two things, the amount of money in your pocket and your connections on the black market. As you know, a pair of nylons could buy a woman's body, a diamond ring could buy her for life-or as long as you wanted. (Boss of Britain's Underworld, 1955, 76).

In 1945, George Ryley Scott, diligent researcher into torture and flagellation, recalled in a book against censorship that:

Following the outbreak of war in 1939, a demand was created for cheap papercovered novels, especially of the type known to the trade as "sophisticated fiction." The result of this demand was seen in the appearance all over the country of those paper-bound volumes, mostly published at a shilling, with alluring picture covers of 
scantily-clad "glamour" girls. In particular, tough American gangster stories were prominently displayed and enjoyed enormous sales. ("Into Whose Hands", 124).

My guess is that the "sophisticated" books that he's referring to were by writers like Paul Renin, Roland Vane, and Jules-Jean Morac, which mostly (see my descriptions in "Jungle Books 2") have a pre-war feeling to them, and, though dealing with sexual relationships, aren't salacious.

As to toughies, I've only been able to come up with a dozen or so paperbacked titles, which I've listed in the Notes. Latimer's Solomon's Vineyard (Methuen 1941) was only in hardback, so far as I know, as was Scott's own torture-packed historical novel The Voluptuous Inquisitor that year. The girls on the covers of Wells, Gardner's Glinto novels weren't voluptuous.

But No Orchids and Lady-Don't were archetypical in their situations, and unforgettable in details. And though there was a freeze after the successful prosecution and heavy fining of Raymond, Kelly, and their publishers in the old Bailey in 1942, books already in circulation didn't disappear. My copies of Road Floozie and Deep South Slave came to me years later from an author who had been left a trove of paperbacks by an army sergeant who had served under him in Cairo.

\section{XXXVII}

Hector and Harold Kelly went into publishing on their own, cautiously, with Everybody's Books, issuing some thirty titles from 1943 to 1946. There's no sex in Harold's The Bronsville Massacre (1943; as by Buck Toler), about a labour conflict, or in his non-toughies as Eugene Ascher and Preston Yorke. The brothers (Hector ten years the younger) must have been preparing to launch Robin Hood books once victory seemed assured, probably with Harold doing some stock-piling of works and authoring the majority of its titles, including pseudonymous Westerns, into which he put some of his best writing.

With peace and the chance to use accumulated paper, other publishers jumped into the act, most visibly at the outset with Ben Sarto and his Miss Mabie Otis, who would be featured in seventeen books.

By 1947, someone was complaining that "lately a great wave of cheap rubbishy stories has invaded the [Welsh] mining villages, and at the stalls in any market you can see these booklets in exciting paper covers with glaring titles, changing hands like hot cakes ... [ellipsis sic] mostly second-hand, and very dirty." (Quoted in David Kynaston's 2007 Austerity Britain, 1945-1951, 186). None of the six sample titles (Dangerous Dames, Corpses Don't Care, etc) is in Hubin, so presumably, like Hoggart's, they were made up.

The spate was under way-Nat Karta, Spike Morelli, Duke Linton, and so forth (over 150 names by the end), the multiple pseudonyms, the lingerie-rich covers that have become collectibles-and would continue until the Mushroom Jungle wilted around 1954 under the chill of prosecutions and newspaper campaigns that paralleled those against horror and crime comics in the States.

As far as was generally known, these were American books by American authors. Some of them were in fact reissued in America, mostly, I think, New York.

So what was going on? Was this all the dread coarsening and brutalizing of Hoggart's polemic? 


\section{Junglies: Functions}

\section{XXXVIII}

353 I believe that the Junglies, in reality a pretty diverse group (I haven't read any of the science fiction), served as an important zone for psychological decompression and the chance to work one's way through a tangle of war-induced attitudes.

America for the young French intellectuals sitting hour after dark hour in the Cinémathèque was vitality, in physical comedy, musicals, B-movie thrillers, horror movies, John Wayne Westerns. No equivalent of musicals like the Astaire/Crosby Blue Skies (1946) or Vincent Minelli's Ziegfield Follies (1945) could have been summoned up in England in 1946.

But in England, and for the British forces, the million-some Yanks assembled in England in preparation for D-Day-oversexed, etcetera-had been far from an unmixed blessing. And for the British, which had fought on after the fall of France and saved the civilized world, as they saw it, peacetime was little better than wartime, while back home the Yanks were enjoying the emergent bounties of technology switched from wartime to peace.

The Junglies were transposers and transformers with respect to America-the idea of it more than the actualities.

In contrast to the movies, the characters were visually generic and easier to empathize with, neither chivalric winners nor gallant losers. And there were no upper classes in the British sense, only the rich, who were likely to be crooked or phony. In the Junglies, Americans became ordinary guys, with a variety of problems, few luxuries, apart from automobiles and cheap liquor, and few things coming easily. And America was where interesting things could happen to ordinary guys.

It was sexy, what with unmonitored apartment buildings and motels. And the sheer size of the continent, and the exoticism of Manhattan, Chicago, Los Angeles, New Orleans, and the deserts, and prairies, and mountains, and forests and bayous, in contrast to over-supervised England, meant that there was always an elsewhere to go to, where one could change one's identity and one's self.

This America was a zone of authorial freedom, too, things not having settled down yet into the typologies of American hardbacks: Damsel in Distress, Man on the Run. Private Eye, Police Procedural, Robbing the Bank, etc.

There are some dullish private eyes in the Jungle, treading the familiar paths-cheap office, secretary, dame coming calling, rich client requiring services, lots of interviewing, almost no bang-bang-as well as treats like Brett Vane's Sunny (1953). There's vengeance-seeking, and armed robbery, and gang-warfare, and on-the-run.

But so far as my own reading goes, there's not a lot of gangster-on-gangster stuff (equivalents of Scarface and Public Enemy), and such gang bosses as we see, like Big Peto in Ben Sarto's Chicago Dames (1946) or Joe Keefe in Ace Capelli's Get Me Headquarters (1949)are largely either unpleasant, or beset with problems of their own, or both.

The commonest pattern in the books available to me is that in which someone, whether private-eye, investigative journalist, low-level gangster (Dillinger- rather than Caponetype), inveigled or trapped bystander, is launched on a course of more or less unpredictable events. 
There can be a good deal of moving around, as Hitchcock discovered with pleasure in Saboteur 1942) and, years later, North by Northwest, after emigrating to the States, and which had characterized Buchan's Hannay novels, but which had become increasingly difficult in postwar England, with few cars still and a network of surveillance that had been established when the invasion of England seemed likely-a mobility contrasting with the claustrophobia of urban British movies after the war like Brighton Rock (1947), They Made Me a Fugitive(1947), Night and the City (1959), and the surprisingly good, if plot-altered, No Orchids for Miss Blandish (1948).

In Ross Angel's Tomorrow-the Chair (1950), for example, gangster Keet Henderson, after an unfortunate incident during the stick-up of a Manhattan club, takes it on the lam with someone's GI bride, Maori Huia Lodge, in Gun Crazy fashion; becomes a nightclub bouncer in Cincinnati; convalesces elsewhere after a beating; returns to Cincinnati to kill a couple of hoods who've raped Huia after she'd helped in a stick-up; goes down to Amarillo, where he screws up the plot of a crooked fat lawyer and crosses into Mexico with some of the spoils; comes back up to Knoxville to crush someone out of jail with information he wants; goes to Memphis; is hijacked on the highway and badly beaten, but nursed by the rich daughter of a cattle baron; and ends up on Death Row after stomping to death a lowlife floozie who's doused Huia with vitriol.

\section{$366 \mathbf{X L}$}

And even when the action was confined to one locale, the author's imagination, uninhibited by editorial monitoring, could be an affair of surprises. As with, to save time and quote myself, Nat Karta's The Foolish Virgin Says No (1953):

Nat Karta, private-eye, who's been to the movies and thinks of Bogie, and Andy Hardy, and several other movie figures at various times, is hired to bodyguard Virgie, a 6' 2" hillbilly girl like Al Capp's Long Sam who's visiting New York and has to remain a virgin for a week longer. If she doesn't, gang boss Vecchiano stands to inherit a lot of money.

At first the consistently staccato style feels like a way of doing a lot of monologuing by Nat without having to provide any strong action.

Suddenly I say the hell with it. Whose joint is this? Mine. Even if I do owe three months' rent. I'm gonna teach this buzzard the facts of life. Fact one's going to be that no cock crows on my dunghill. 'Cept me. Fee or no fee. Client or no client. I bang my desk. I hurt my hand. I even hurt the desk. It ain't built to stand real wear and tear. But I get Brother Grimes' attention. All of it. Every bit he has. He looks at me. Glowers. Licks his lips. Shifts around. All that guff. (15)

But by page 52 Nat's administering a beating in a ruined house to one of Vecchi's boys, a fat sadistic queer who's trashed Nat's office and broken all four paws of the office-building cat before killing it. After which Nat fastens his wrists and ankles with copper wire, gags him, smears ripe cheese over his face, neck, and hands, and leaves him to the literal rats.

After which:

Virgie displays her strength and wrestling skills in a men's gym and shoves a cream cake into Vecchiano's face in a tea-room. Nat is arrested on a frame-up by a corrupt cop and bailed out by an honest one. A couple of Vecchi's hoods snatch Virgie and gut-shoot one of Nat's two employers. Nat tracks them down, kills one of them in an alley shoot-out, challenges the other to a fist-fight, wrecks him with the help of a roll of quarters in his fist, pounds out of him where he took Virgie, and leaves him gut-shot and screaming.

He makes his way to the lowdown night-spot of immensely fat Moll Mazurki, learns from her that Virgie is now at Vecchi's place, and saps her unconscious, pausing 
afterwards to set the club ablaze with gasoline from the punctured tank of a parked care. At Vecchi's he fights with a large Negro who was getting set to rape the now drugged and passive Virgie for the entertainment of a select group behind a oneway mirror, does badly, and is saved by a friendly Doberman who rips out his opponent's throat.

After which he fights with Vecchi himself, who proves unexpectedly skillful and dangerous until Nat finally breaks his spine across his knees. After which he lines up and photographs the dignitaries behind the mirror and exits with the still virginal but sexually demanding Virgie, with whom he does not in fact sleep.

A treat? Well, actually yes. Though the author doubtlessly read Spillane and, for a lighter touch, Richard S. Prather, the manner is all his own, and though it will sound paradoxical, the book seems to me not sadistic in the way that the early Spillanes were, maybe because it's less realistic and moralizingly punitive than the latter and more concerned with the solving of problems for which violence is necessary, without lingering over the losers.

This is more that big-city America of the British mind that figures in accounts of the jungle books, here in industrial strength, with Nat running real risks, the way that the Man with No Name does in the Sergio Leone Westerns, those other over-the-top adaptations that leave one perked up rather than depressed. Since his efforts go into keeping Virgie virginal, he isn't particularly sexy either.

368 XLI

369 These were books in which, so far as you could tell from the cover, anything might happen, and in which the forces of law-and-order don't figure prominently. There isn't a single cop novel among all the ones that I've read. And there was no obligatory noir pessimism, since in contrast to the States, there was no washing-machine-and-familycar prosperity in Britain whose dark underside needed pointing out.

They were also books in which a broad latitude was permitted with respect to styles, with at one end Gold Medal Books competence like:

She was tall for a girl, if you can still be that when you aren't going to see thirty anymore and she wasn't. Five feet nine would be the height rating if she got down off the high barstool and let somebody measure her. She wore a green-and-whitestriped cotton cord two-piece and a white cap sat on top of a lot of shining blueblack hair which fell in one of those tremendous off-the-face cuts. She looked cool, relaxed and desirable, but I didn't tell her. I thought she had known that for a long time. (Dale Bogard, Nobody Died for Johnnie, World, 1951, 1)

And at the other end are sentences like, "He would go out with holes in him big enough to allow the whole of his inside to discolor and ruin whatever carpet he may be standing on at the time" and "A clucking sound of obvious displeasure dribbled from his mouth along with a slight foam." (Michael Storme, Hot Dames on Cold Slabs (Archer, 1950), 86-89).

Though Steve Holland tends to emphasize the hackwork in his ground-breaking The Mushroom Jungle, the Jungle freedom, if you liked writing, must have made life more satisfying for a lot of its denizens, who mostly wouldn't have had a hope of breaking into the Penguin and other over-the-counter markets.

Things were easier, too, because there wasn't for Jungle authors the indignation, given the discrepancies between wartime What We Are Fighting For propaganda and the actualities of organized crime and civic corruption, that energized returning American veterans like John D. MacDonald, Kenneth Millar (John Ross Macdonald), Charles Williams, John McPartland, and Mickey Spillane.

But surely Hoggart was right, these were violent books, I mean VIOLENT. Weren't they? 
Well, yes and no. There's a difference between books in which violences entertainingly occur and ones that induce a state of disquiet in you because feeling violent, either because of realism, like Hubert Selby Jr.'s Last Exit to Brooklyn (1964), or because the violences seem to be the whole point, with the in-betweens, the recitative as it were, merely surfaces, like in Italian giallo movies where the in-betweens are so dull that you welcome the violences because at least something is happening.

There are indeed disturbing passages, such as the following in Ace Capelli's Get Me Headquarters (1949):

Duval gave her a hard shove. She staggered, fought hard to regain her balance, and one foot slipped over the edge of the cliff. She fell then, her eyes wide with horror, screaming madly. She fell so that her legs dangled over the edge while her arms sprawled over the lip of the cliff, scrabbling, digging into the ground, trying to save herself. The two men stood there looking down at her while she screamed and raved and tried to climb back. Neither man moved except when once she looked as though she might claw herself back to safety and then Duval stepped forward and brought his heel down savagely on her fingers. They stood there watching while the strength went from her arms, watched as she slid backward, slowly, slowly, her arms flagging, her fingers, bleeding, digging into the ground. They watched until her arms slipped from the edge of the cliff and only her fingers held and they still watched as the fingers lost their strength and finally released their hold. And they watched without emotion, watched as sanity changed to madness in the girl's eyes and as life changed to death. Then they listened as the long scream went hurtling down onto the sharp rocks two hundred feel below and checked abruptly.

Stephen Frances (Capelli here) can be very disturbing. He was obviously fascinated by pain (his In the Hands of the Inquisition [1971], as byMaria Deluz, is harrowing) without being, in the S-M sense, sado-masochistic. It's as if, like someone who'd read those allusions to unspeakable cruelties and missed out on military service, he wanted to imagine for himself what it might have been like to be two American girls in a Nazi concentration camp (Women Hate Till Death, 1951), or an abused wife moaning and whimpering in the next bedroom, or a guy being third-degreed by a cop who believes him guilty as hell and loathes him (Accused, 1954).

Cf., at a far higher level, Stephen Crane writing The Red Badge of Courage (1893) in order to figure out how he might/should/could have conducted himself in that conflict that was still the biggest thing in American minds while he was growing up. In Lions and Shadows (1938) Christopher Isherwood recalls having bought a large motorbike after the Great War in order to make himself experience The Test.

Frances was a strange, sad, self-defeating figure, whose three "real" novels about the aftermath of the Spanish Civil War, collected as La Guerra (1970), were impressive (and contained the most horrible and all-too-credible incident of cruelty that I have encountered in any novel).

But there is relatively little gratuitous violence of the kind that one finds in a novel like Steve Markham's The Hideout (1950)or William J. Elliott's Freak Racket (1942), in the latter of which we're told of a naked hood bound hand and foot and burned in a bath of paraffin, and another is seen spreadeagled and screaming on the floor while being eaten by rats, who've already made "great, bleeding holes" in his arms and legs and gnawed away his left cheek, with the Lemmy Cautionesque narrator describing how, being seriously annoyed with a woman, 
I smacked her, fore and back-handed, on both sides of her face with all my strength. Then I doubled my fist and smashed her on the nose, and felt it crunch and flatten under my fist. Then I threw her down and grinned at the handful of rich, dark hair left in my paw. ... [T] he last thing I heard was Julie screeching as they dragged her off to the room where all the boys were. (178)

\section{find something out, or in self-defense, or to eliminate someone dangerous. Person-to- person killings may not be tidy.}

\section{XLIII}

\section{And even when sociopaths are at work we know that that is what they are.}

A chapter in Brett Vane's This Honey is Mine (1950)ends with: "Her eyes were closed, so she did not see him stoop over the corpse of Nick Pollock and heave out the blade, and then Eddie, leaning across her, flashed the knife in a single stroke which cut her lovely throat from ear to ear." (50). Which is immediately followed in the next chapter by:

The massacre of the Schentuck boys was afterwards filed as one of the biggest home news stories of the year. Fifteen hoodlums in all met violent death in a variety of forms. Some got it swiftly with lead, some lay writhing in dreadful agony from knife wounds that had torn their stomach apart; others were discovered with their faces battered beyond recognition, and a couple were strung up from posts in back alleys. The Press boys had a gala night. Hard-boiled New Yorkers, reared on sensationalism, went green when they opened their morning papers over breakfast.

In this 128-page small-print account of the rise of psychopathic/sadistic Eddie Ball to the top of a city's crime empire, the narrative is dense in its tracings of power relationships and Eddie's hang-ups with women, like an extended Cagney movie with Cagney at his most White Heat vicious. There is no hero-worshipping of Eddie in the narrative, and no lip-smacking lingering on the violences. They are how Eddie convincingly behaves, character-driven.

\section{Even the following from Spike Morelli's You'll Never Get Me (1950) is in character:}

I kicked his face again and heard the crunch of bone. The next kick loosened his teeth in front and then I contented myself with going at his body. The more I did it the more the blood seemed to pound through my head. I was back in there in a cell and that buzzard was giving me hell with a sap. I didn't know what I was doing or how to stop myself. I was down on my knees beside him with a pocket-knife in my hand. I was tearing at his clothes to get them away from his fat belly. Then when the big white fleshy expanse was laid open for me I gave him the knife. I didn't know what I was doing; it was like I had gone mad and couldn't hold myself. The knife went in and out deep every time until the blood was spurting in all directions. I dug it in and in again savagely, twisting and turning it, until I hadn't the strength to carry on any more. I got unsteadily to my feet and looked down at the bloody mess that had been a cop and I laughed. (67)

There is nothing like it in the rest of the novel. The victim is a cop who had led a savage third-degreeing of him.

9 At times, as with The Foolish Virgin Says No, where there is little lingering, one registers subliminally that the violences, while extreme as described, and not impossible, are highly unlikely to be real-world. The body-count of hoods gnawed to death by rats in empty houses after being smeared with cheese can't have been high.

I take up in Violence in the Arts (1974) the question of what makes some violences disturbing, while others, like those in The Man With No Name Eastwoods, do not. Like "stresses" in metrics, violences derive their effects from their contexts. 


\section{Violence: Decompression}

\section{XLIV}

But "mere" entertainment, as we've known for a good while now, can be a serious matter, a repertoire of ways of coping with and defining aspirations, hopes, fears, possibilities, denials. And the Junglies served important functions beyond the pleasurableness of a temporary time-out from the slow-paced or hectic quotidian.

Postwar-1946 plus-was a time of sudden decompression, lost momentum, unwanted energies. It was more than just that lots of young men (deprogrammed away from the interwar docility ) had been trained to kill and urged on towards it, and required to be brave, whether in battle or under interrogation. The momentum ("screw your courage to the sticking point") built up for dealing with Nazis and Japs was abruptly halted.

There were numerous possibilities and attitudes in that momentum-bringing bad guys to justice; self-defence; advancing into danger bravely; collaborating with others; not letting down the side; exercising authority; making decisions for others; not betraying others; discovering one's real self; protecting innocents; obeying commands; ignoring foolish or improper rules; comforting the wretched; displaying problem-solving inventiveness; making pragmatic alliances; the problems of ends-and-means; collective guilt; forgiveness; the appeal of "winning"; the chivalric versus the machiavellian.

The end of the war was a time of major confusions, what with floods of unsorted refugees, SS men gone underground, the difficulty of distinguishing between Nazis and others, the problem of what to do with a devastated Germany (there were high-level American disagreements), the gaps between official Stalinist statements and actual behaviours, the realpolitik of exempting Nazi scientists from scrutiny in order to profit from their expertise.

Intellectuals were at work on some of those matters-Sartre, Orwell, Koestler, Camus, others. Sartre wondered how one would behave under torture. Rossellini's movie Open City (1945) perfectly encapsulated wartime situations and character-types, including a Resistance leader dying under torture, with glimpses of what went on in that room, in which at one point, bare to the waist, he sits quietly as one of the torturers straps him into a chair while a blow-torch flames nearby.

I myself, as a first-year undergraduate in 1948, was fortunate in being able to begin with Shakespeare rather than Chaucer, and felt my way along with him politically as he worked on comparable issues.

8 But at a lower cultural level (with an expected return to Hoggart's decent normality), what was there? Those wonderful group wisdoms and common sense of Hoggart's pastoral community (absent strikes, lock-outs, shop-stewards, unemployment, violences, the sack, the dole) weren't self-generating. Groups are individuals, and individuals have individual experiences, even if not talking about them, or concealing them behind group phrases and formulas. A Guards officer when asked what it had been like at Dunkirk, famously replied, "My dear, the noise. And the people."

The Junglies offered a rich variety of experiences, attitudes, character types, behaviours-honest, dishonest, in-between, as characters changed under pressure.

I shall focus here on women and violence. 


\section{Violences: women}

$401 \quad$ XLV

402 The returns of warriors to wives and sweethearts were not always idyllic, despite or because of idealized yearnings (as in the saccharine rural peace of "The White Cliffs of Dover") and the simplifications and role-playings of letters. Paradoxically, I think the junglies performed a benign function with respect to women, a number of whom had been in the Services themselves, while others had enjoyed the independence of factory work, with problems now about men in search of their old or better jobs.

Men were returning with experiences not easy to communicate-not just the bad ones, the killings, the deaths, but also the intense male bondings and camaraderie, and maybe the occasional sexual episode, and even, with it safely past, a certain adrenalin thrill (North Africa, Italy, Normandy). And you'd be likely to be coming back to someone wanting you all to herself, with a home and kids in mind, and with her own tales of hardships and rationings and queues and making-do, someone hungry for conversation, for talk, and for whom, in comparison with the here-and-now drama of kids, your own experiences are really, however tolerantly she listens to you, a bit insubstantial.

And there were particular problems with violences against women.

If war was killing, war was also rape, or the virtual rape of sex sold from desperation and poverty, being the revenge/temptation of conquerors, with enemy males absent or disempowered. A thematic key had been set with the kidnappings, floggings, and rapes of No Orchids for Miss Blandish, Lady-Don't Turn Over, and Miss Callaghan Comes to Grief.

But overwhelmingly the Junglies that I have read were not equivocal about rape, not like the later Marcus Van Heller books of the Olympia Press, or earlier submission narratives like Jean de Villiot's Women and Her Master (1904) and E.M. Hull's vastly popular descendant from it, The Sheik (1919).

"White slavery," a term covering kidnapping, virtual enslavement in Latin-American brothels, employment in businesslike Paris brothels, and street-walking with pimps, had been a preoccupation with reformers since W.T. Stead's Maiden Tribute of Modern Babylon and his exposé "purchase" of a virgin in the 1880s, with intensified American campaigning in the early 1900s. And it indeed offered opportunities for salacious fantasizings. In a paperback contributed to the library that I operated at school for a year or two from a suitcase under the stairs (you donated a book to join it), there was a reference to new girls being hunted naked through an indoor maze with padded alcoves. And Lady-Don't Turn Over is powerful in that regard, as the Crown prosecutors recognized.

The literally imprisoned well-to-do sex slaves of Lady-Don't and Miss Callaghan were almost certainly fantasies in the America of the Thirties. The dynamics of enslavement were much more likely to have been those detailed in Edgar Wallace's On the Spot (in whichwomen with nothing else to sell slide downwards into cheaper and nastier houses as their looks fade and their novelty wears off. The Chicago whorehouses of Warren Smith's admirable and unsalacious Bessie Cotter (1935), which cost its British publishers the equivalent of ten thousand pounds today in the Bow Street magistrate's court, were normal commercial operations, like French brothels before Marthe Richard pushed 
through the French parliament in 1946 her law that shut them down.. The last thing that madams wanted was trouble with the authorities.

But obviously there were girls being kept against their will in American brothels before WW1, and Orwell's own equivocal come-on at the start of Down and Out in Paris and London raised questions about sinister possibilities in a Europe where money could buy anything, an idea alive and well, still, in the Hostel series.

410 And the fantasies were powerful distillations, connecting up with wartime talk about Nazi atrocities, as in Sir Robert Vansittart's Black Record; Germans Past and Present (1941), the text of six BBC talks, given with government approval, which I read around that time:

The Gestapo and the Black Guards of the concentration-camps have steadily increased the methods of anguish that the strong can inflict on the weak, when they have bestial and ingenious minds. The excruciating torments for the human body are beyond belief, and beyond forgetting. I am not, however, going to harrow you with a detailed catalogue of horrors, under which many prisoners, Jews, Czechs, Poles, and Germans too, have slowly expired ...

What can Hitler's alleged passion for Wagner and architecture matter so long as Czech students can be shot for singing at a funeral, and ten times as many be mutilated and done to death on any pretext or opportunity? And Germans raped the girl-students in the presence of the boy-students before they shot the boys. And many others-boys and girls-have been so handled as to prevent them from ever having children. ... And great numbers of Polish girls have been forced into brothels for German soldiers, and there worked to death. (46-47, 53-54)

\section{XLVI}

In the "sophisticated" fiction of Roland Vane, forced prostitution is something to be dreaded, a pit into which the unwary may fall:

That night, Merle knew, she and the others would be forced to go through the same routine again. First there would be their dancing act and then-she shuddered at the very thought-they would have to mix with the customers. There would be more of them coming to her room.

And this would go on night after night, week after week, month after month, year after year. There was no hope. She was doomed-doomed to this life of infamy and shame until such time as her health broke down under the strain and, weary and useless, she would be thrown on the scrap-heap in a strange country, to fend for herself as best she could.

Merle quickly lost count of the number of times she had been forced to go up and down those stairs, and the number of lovers she had been forced to "entertain." The kinds of men who patronized Senora Juana's place were the dregs of humanity, and she was appalled at the depths to which they could sink-and to which they dragged her. (White Slave Racket, 108)

Chase's Miss Callaghan Comes to Grief (1941) is about the mechanics of sexual subjugation and the gratification of breaking free and taking revenge. In Glinto's No Mortgage on a Coffin (1941), it is what Hester Mecklen is almost condemned to. In Michael Storme's Unlucky Virgin (1948), it is a looming dread destination, with the possibility of rape en route.

Rape and degradation can be mind-destroyingly horrible, as in Janson's Women Hate Till Death and Rosa Van Sennes's certainty in Glinto's Blue Blood Flows East (1947)of what it would be like to be in gangboss Dropeye Grimson's hands for twenty-four hours. In Lady -Don't, we yearn to warn poor naive fleshy Edda Van Luys as she wavers in the roadhouse bedroom between self-protective suspicion and wanting to trust Mouth 
Fennig as he soothingly circles closer and closer to the moment when, after getting her to write a reassuring note to her parents, he leans over and turns out the light ...

\section{XLVII}

Horrible things can happen to women in these novels, as they can to men. There are no magic shields, any more than in the wartime actualities of the camps, and the Gestapo torturings, and the Japanese atrocities in 1937 during the Rape of Nanking.

at times nothing that they can say or do can get them spared, like the terrified cliff-edge victim in Get Me Headquarters or the anonymous hitchhiking women in Nat Karta's Love Me, Hurt Me (1952) who, while cheerfully sexing with a truck driver off in the bushes, witnesses a murder by a couple of hoods and is spattered with the victim's blood.

When she screams at the touch of one of the hoods ("worse than if he is breaking her arm"), "It isn't so much what they are set on doing to her then that is bothering her so much although she scunners with every slimy touch and every nauseating movement, but what she knows damn well is gonna happen to her when they get through."

Rescues and reprieves do not necessarily come in time.

In Glinto's Road Floozie (1941), insult is added to injury as heavy motor oil is poured onto the half-naked Eilleen as she lies on the bench seat of the truck after a triple rape.

\section{XLVIII}

But women are not just victims, and there's no Whore/Prude dichotomy.

There are lots of different women in these books-Glinto's Carrie Donovan in Curtains for Carrie (1947) and Connie O'Mara in No Come Back for Connie (1948) confidently running, proto-Modesty-Blaise-like, their own criminal organizations of men; showgirl Cora Bilt in Lady-Don't deftly stringing along her senescent Guy-Kibbee-like sugardaddy; women savage against men, like Sarto's Mabie Otis in Miss Otis Comes to Piccadilly lashing little Sir Surtees with a poker; women cruel against women, like Rita gouging the cheeks of rival Sonia with a pair of scissors in No Mortgage; little sparrows, like Stella in Duke Linton's Too Late for Death (1950; Duke Linton here being Frances); gunmoll partners of small crooks; perky girls like Bernice Barrado in Vane's Goodbye, Honey (1953) holding a parsimonious story-seeking editor's feet to the fire over the phone with a coolly reiterated "One grand"; office girls saying things like "I don't want to walk in on love's young dream... But I've got business to discuss with Chirp. Would you mind throwing your body under a truck or something, honey?" (Goodbye Honey, 101); French girls like Minette in Jules-Jean Morac's No Prude, learning the rules of the game in Monsieur Louis' art-photography studio and going along with them.

Plus an unexpected moralism about girls wanting to "live." Mr. Right, in more than one novel, turns out to be a smoothy cad. The snobbish parents of nice-but-weak Noel Gibbons in Paul Renin's She Who Hesitates (1953) decisively reject his decent village girl (who does not, caveat emptor, wear a black satin negligee like the one on the cover). Dance troupes excitedly off to foreign parts learn too late what they're in for. And when it's pay-back time in a toughie like Brad Shannon's The Big Snatch (1952), we are likely, if a bit nervously, to applaud:

When [Sue's mother] came back four hours later she had a couple of drunken sailors with her. "This is my girl, boys," she said, "She's a beauty, better than all your Park Avenue dolls. But she's kinda stubborn at times. You don't have to take 
any notice 'o that, that's just her way." After which Bella teetered out again and was seen no more that night.

Sue was stubborn all right, she bit and scratched like a tigress. But she didn't stand a chance with the Navy. They had their way with her and left her half submerged. When Bella returned the following morning she was surprised to find her girl lying calmly on the bed smoking. She was naked except for a small house-coat. "Don't bring me any more drunken sailors," she said, "they don't do it properly and they don't pay enough."

"I won't, dearie," said her mother and flopped down beside the bed. Sue hit her with the weapon she had held hidden under her coat. It was the brass Indian. She battered her mother's head in with it, hit it again and again like she had seen O'Toole hit her father with it years ago." (96-97)

\section{XLIX} company. bootlegger. beloved Angelo.

Kelly himself, the most intelligent of the Jungle authors, had an ongoing interest in women who, unlike Miss Blandish and his own Doreen Milmay in Lady-Don't, refuse to internalize a victim status.

He himself had undergone a species of violation when in 1933 the newspaper City MidWeek, which he and a fellow journalist had created the previous year, and in which he himself reviewed City of London cultural events and did a belle-lettristic column celebrating City types and traditions (collected in 1951 over his own name as London Cameos), was smashed flat in a High Court libel action by a Canadian insurance

In No Mortgage,Hester realistically acknowledges that, yes, gangster Sam Lemberg, whom she stands up to, will have his way with her if he wants to, being more powerful, but no, she won't allow it to destroy her. In You Took Me-Keep Me (194), young Edda Garfe tells young roughneck Max Broder, after the act, that she'd been saving herself for something better, but that they're partners now. And she helps him to succeed as a

Eilleen Rourke in Road Floozie, anticipating figures like Thelma and Louise, gets a gun and avenges herself on innocent truckers. Francesca in Tough on the Wops overcomes her normal nice-Italian-girl timidity and, at great risk to herself, kills the killers of her

And in the Westerns that Kelly wrote as Lance Carson and, very probably, Clinton Wayne and Bryn Logan, and into which, after a bit, he was putting his best energies, there are a number of brave heroines unfazed by the fact that good guys-chivalric heroes following their own codes-have to use violence against bad.

Except in Miss Otis Comes to Piccadilly ("Tiger eyes, flooded with awesome light, stared into wolf eyes, glaring and bloodshot"), I nowhere encountered the sexual grapplings of human beasts that Hoggart describes. One's more likely to have shooting stars, bells, lightning flashes, and the like.

But, as I've said, Hoggart no doubt read works that I haven't. In any event, to judge from the sample first names that he provides, he's talking of before the 1953-54 trials that sent a couple of publishers to prison with heavy fines and caused the Kellys to sell the Glinto name to Frances.

What we see in all this is a diffusion of concepts.

There isn't Woman, whether with halo or horns, a composite being inviting adversarial generalizations. There are individual women, just as there are men, who aren't 
normally dichotomized. (Jocks and Wimps? Cocks and Capons? ). Actually there's a good deal of variety in Gold Medal Books too. But Americans, including women themselves, were more prone than were the British at that time to wanting to know whether a girl was Good or Bad, since the omnipresence of the automobile made more urgent, on nighttime excursions, the question of how far a girl was willing to go.

\section{Part 4}

\section{Concluding}

$435 \quad \mathbf{L}$

In that difficult but fascinating poem "Lul de Faltenin," Guillaume Apollinaire, who had himself descended literally as well as figuratively into the collection of forbidden books in the Bibliothèque Nationale, and in 1907 penned for money the ultra-sex-andviolence Les Onze Mille Verges (The Eleven Thousand Canes/Pricks), which doesn't seem to me as funny as it apparently does to others, presents in symbolic terms the fascination of the descent into the grotto of the Sirens-the erotic, the forbidden, the dangerous (see Bibliography).

A number of portals have figured in this article, some entered by me, others by other readers and viewers. Not all portals can be safely stepped through. Not everything is fun, or camp, or irony. The works of Sade, that Dark Continent haunting the sexual imagination during the nineteenth century and on into the twentieth, could make the incautious, like Mister Kurtz's young Russian acolyte, see "things-things," as does the immense realm of Pornotopia on the Web today.

But a lot can depend on the spirit in which one explores.

Personally I've read the Junglies in the way I would read any novels, which is to say, not seeking clues as to whether or not a work is "literature," meaning innately good and charged with insights, but with an eye and ear turned to the kinds of codes and what Yvor Winters calls "operative conventions" at work in it, and how well it does in relation to them, and have been pleasantly surprised at times by inventiveness and/or craftsmanship.

Jünger's narrator in On the Marble Cliffs prudently stayed away from the dark barn, just as Jünger and others stayed away from an engagement with the fact of the Nazis' concentration camps and torture chambers.

But Apollinaire remained down there in the basement of the Bibliothèque Nationale, and, in company with Louis Perceau, later bibliographer extraordinaire himself in Bibliographie du Roman Erotique au XIXe siécle (1930), catalogued the holdings in L'Enfer de la Bibliothèque Nationale (1913), bringing order, or the ground-work of order, into an area of the mysterious, the dark, the sacrilegious.

And in Ulysses, where Joyce, going way beyond his own adolescent confusions about sex-and-religion, mapped literal Dublin, and figurative Western culture, and personal configurations, Nighttown, with its dissolvings and re-synthesizings, is an integral part, in contrast to the low-energy masturbation of Leopold Bloom, reader of mild erotica and voyeuristic peeker at Cissy Caffrey on the beach. 

book of jokes.

Elsewhere, in "Thrillers," I talk about a body of mainstream works that I have been reading for pleasure, not "studying," for fifty years, and recommend, as if to someone curious as to what the term "thrillers" might cover, a number of authors, along with offering some general reflections. "Reading Thrillers" is the nearest thing in my work to the formulation of an aesthetic that encompasses thrillers, "serious" fiction, and poetry, especially formal poetry.

It wasn't a stressful undertaking, except when I tried to go deeper into a few works that I found particularly rich. When you're reading a lot in a genre for your own pleasure, you know what you're enjoying, just as you know what jokes you find funny. You know, for example, that you've been particularly gripped by American thrillers like Charles Williams' Scorpion Reef (1955), Donald Hamilton's Line of Fire (1955), John McPartland's The Face of Evil (1954), Kenneth Millar's Blue City (1947), and John D. MacDonald's Death Trap (1957). You were there, drawn on and on by a pleasurably anxious curiosity as to what would happen next, and next, and next, enjoyably caught up in unputdownability.

Exploring the Jungle hasn't been like that, not even, or perhaps especially, when concentrating on for me the most interesting of the Jungle writers, Harold Kelly, alias Buck Toler, alias Lance Carson, alias ... Things simply haven't shaken down into the kind of pattern wherein, as with the glorious Gold Medal books, you knew after a while how the experience that you were getting from this or that particular work resembled and differed from what you had been getting from others. So doing a sort and trying to decide what the "best" Junglies are would be premature, though I know that Kelly's three best Glintos are Road Floozie, Deep South Slave (not a toughie), and, despite some flaws, Lady-Don't Turn Over, and that several of his Westerns, such as Lance Carson's The Trouble Kid Quits (1951), are remarkable.

447 LII

But this indeterminacy is partly a strength. As Joyce Cary points out in Art and Reality (1958), works can wear out, even good ones, and with a lot of Gold Medal books , returning to them now can be an As Though affair, namely trying to read or reread as though one were back in those years, but experiencing, not period actualities so much as period attitudes. Too many of the social features that Travis McGee complains about have been long overtaken by worse ones, just as the Playboy Philosophy is no longer a guide for aspiring young dudes wanting to know how to cope with the maitre-d' on a date. Retro can still have its charms, but it can also be numbing, like trying to read a

The Junglies, even clumsier ones, can feel fresher, being by writers who, aside from some Private-Eyedom, don't have a formulaic sense of what genres they're working in. They are simply... writing. Fast. And especially they aren't noir, which is to say, infected by a Hardyesque pessimism and sense of the inevitable defeat of hubristic aspiration. So the Jungle is still a zone of energies, and of the unknown, so many of the works having vanished from the marketplace.

It was reassuring coming upon that recollection by witty, prolific playwright/novelist/ diarist/Leavis-admiring academic Simon Gray that is one of my epigraphs. As elements in the adolescence of bright young British mavericks, the way that EC Comics were for future American writers and movie-makers, the Junglies, I'm sure, would have been liberating, as against the depressiveness of the British class system, with its Latin- 
quoting snobbery at the top and philistine sneer of "big -'ead" (i.e., swollenheadedness, or getting above oneself) down below.

\section{LIII}

So it was a relief when the Sixties succeeded to the Fifties of low expectations and sunless horizons.

It was a treat encountering in Len Deighton's Ipcress File (1962) an unpatronized industrial-strength America out on the Pacific atoll, with pitch-perfect American speech, in contrast to the two-dimensional America of Fleming's Live and Let Die, with its implicit British superiority reinforced by the reduction of the American power machine to a nice-guy FBI agent with the highly improbable name (given Mr. Hoover's prejudices) of Felix Leiter-and a hero whose unreality is all the more glaring in comparison with the American protagonists of MacDonald, Williams, McPartland and others who had been entering England in the Fifties with the easing of paper restrictions.

The friendly reception given to Fleming's violences-Le Chiffre's carpet beater, Mr. Big's projected towing of the naked Bond and Solitaire across the coral reef-was interesting. The Bond books were Bulldog Drummond (not Hannay) updated-a knowing return to, and intensification of, ruling-class thriller violence.

"Sapper" had been almost Fantômas-inventive at times in his Drummond quartetthumbscrews, an acid bath, and a lethal pendulum in Bulldog Drummond, a bomb, an electric fence, a paralyzing drug and a master-of-disguises villain $\mathrm{n}$ The Black Gang, a diamond-creating furnace in The Third Round, poison to be sprayed down on London from a dirigible in The Final Count. Plus Drummond skewering to the wall with the latter's own bayonet the red-headed Bolshevik Zulowski who was all set to brain wife Phyllis with the butt of the rifle that had helped butcher the Russian royal family.

And after Ipcress, with its working-class narrator-hero jauntily holding his own against Establishment types, came the first of Peter O'Donnell's glorious series of Modesty Blaise novels in 1965, with working-class Willy Garvin perfectly at ease in any company, and a rich ambience of aesthetic enjoyment. Plus Sergeant Pepper two years after that, encompassing the "traditional" British coziness of "When I'm Sixty-Four," and visionary LSD tripping, and the urban burn-out of "A Day in the Life," along with the bravura dissolution of conventional class-cultural boundaries in the collage portraitgallery of the album cover. With Jumpers (1972) and Travesties (1974), Tom Stoppard exuberantly reversed direction in theatre by 180 degrees, into a game-site of highbrow culture as agonistic intellection.

458 LIV seeing the movie, and reading:

Jack, he'd say, those seventy-eights I got yesterday in Arcade, don't you reckon that one by the Benny Goodman Sextet Don't Be That Way, was the best? That drumming by Gene Krupa. Hell, wouldn't it be great to be able to do that? But if you could, you couldn't do it in this hole. Nobody's interested! They'd say it was a row. You can do things like that in America. They encourage you because they think jazz is dead good. America. That'd be the place, though, wouldn't it?

"Imagine," he goes on: 
Those cars with all those springs that rock back and forwards like a see-saw when you put the brakes on. You can drive one of them when you're sixteen over there. Just think, our kid. Driving one of them along one of those highways wearing a drape suit with no tie, like Richard Widmark, with the radio on real loud listening to Benny Goodman. Cor! I reckon when I leave school I'll go to America. Work my passage. I could easy get a job. Even labourers out there get fifty quid a week. Electricians and that can get two hundred. They can. And you can go to pictures at two in morning and see three pictures in one programme. You could get one of those houses with big lawns and no fences.

461 I myself, in 1951, had yearned for a jacket that would drape like Joseph Cotten's in The Third Man. Alas, the local tailor to whom I took some precious tweed, didn't cooperate. He even put a single vent at the back, rather than a pair.

462 LV

What Lewis had effected in Jack's Return Home-a novel every bit as worthy of being taken seriously as those of Chandler and Ross Macdonald-was an important synthesis. In the 1930s, chivalrous effectiveness, including killing (can you imagine Leslie Howard or Robert Donat ever killing anyone?), had been embodied in Americans like Cooper, Fairbanks, McCrea, Gable, along with a new-style print insouciance in Latimer's Lady in the Morgue, Headed for a Hearse, and The Dead Don't Care.

A good deal of energy in post-WW2 America had gone into creating heroes who had been in the war, and understood dangerous men, and were prepared to be effectively violent themselves, but who wanted to settle down into civil life.

With variations in one direction with individuals driven by a hunger for punitive violence, like John Weather in Millar's Blue City, and in the other the later Forties heroes of Hamilton, who were concerned with using their minds in order to avoid or mitigate violence. And, in some of the protagonists of writers like Williams, McPartland, and Lionel White, a working-through of the lure of the femme fatale and the hoped-for big score.

466 In the Sixties, figures like Travis McGee and Matt Helm chose ways of life in which violences were integral parts, but were also capable of enjoying the amenities of civil living.

467 With the Carter of Jack's Return Home, Lewis created a high-energy, high competence chivalric (not chivalrous) British hero, self-defining, analytical, with senses alert to a range of feelings, and the equal of any American. A man mordantly conscious of the phoniness of those in his Midlands home town who had taken on only the hedonistic features of America. A man whose profession was violence.

Lewis, whose first novel, All the Way Home and All the Night Through (1965), was provincial-realist, had stepped through portals and descended into the cavern of himself and, with the encouragement of his remarkable wife, had created unforgettable character-driven violences like the killing of Albert, who'd been in the porn movie with under-age Doreen, possibly Jack's own daughter:

I gave him the knife. I put it in just below the ribs, thrusting upwards. Albert's eyes and mouth opened wider than they'd done at any other time in his life. I left the knife where it was for a moment or two then I pulled it out very slowly, then put it back. Albert began to slide down the side of the pan in silence. I pulled the knife out for the last time and watched him die. 

Fitzgerald, so important for them both, after Gatsby. But some kinds of order-bringing, with opposites held in creative tension, don't need repeating over and over in order to have their effect. $471 \quad$ LVI

Lewis would have read No Orchids, and Solomon's Vineyard and Blue City, and Junglies, and been emboldened by the freedom of Jungle authors to go wherever their characters took them.

He never did another book as good, nor did Deighton after Ipcress, nor did Scott

472 Moreover, those embattled defenders of serious standards, the Leavises, had a view of England and "Englishnesses" a good deal different from that lovable, warm, collective working-class mulch of Hoggart's.

473 Q.D. Leavis referred favourably in Scrutiny to the American-seeming B. Traven (whose Death Ship Orwell thought was nothing much) and Wallace's On the Spot, and wrote importantly on Hawthorne and Melville. One of the three novelists given extended analysis by F.R. in The Great Tradition was American. And turning his attention, postScrutiny, to things American, he put Twain's Puddn'head Wilson onto the map, and redefined the Great Tradition to include Hawthorne, Melville, and Twain. Scrutiny itself had contained appreciative high-energy discussions of American literature.

474 There was something a bit thrillerish, too, about how F.R. dealt with fiction and what he singled out.

475 Leavis's Conrad, who owed so much to Stephen Crane, was the Conrad of dramatic character-testing experiences, with major forks in the road. The wartime Victory (1915), "So 'seen' ... as to invite the attention of the cinematographer" (The Great Tradition, 206), was a quasi-allegory of fin-de-siècle irony confronted with début-de-siècle violence and a rape narrative in posse, with over-civilized and irony-eroded Axel Heyst painfully conscious of what would happen to Lena at the hands of the three invaders if he couldn't protect her. Nostromo (1904) was a narrative in which torture figured prominently. Heart of Darkness (1903) was the progenitor of innumerable Dark Jungle movies, and The Secret Agent (1907) of innumerable thrillers.

476 And Henry James was a heuristic author of major choices, mysteries to be worked on by characters (among them young Maisie in What Maisie Knew), and at times quiet sadism and sexual corruption, who created that memorable hybrid The Turn of the Screw. The ghosts are real and malign (if you don't believe so, you don't know the abundance of British ghost stories), but the thought-processes of the governess, in their selfsufficiency, are American.

477 The Leavises also wrote admiringly about Dickens' high-energy explorations of a society that had not yet settled down into a wodge of class strata and sound administration-an England more like post-Civil War America than that of Trollope, or Hardy, or Galsworthy, let alone Orwell's in the Thirties, and Braine's and others in the Fifties.

478 Somewhere or other, Leavis remarks that "America was where Americanization happened first."

\section{LVII}

Of course there's an element of transgression, of taboo-breaking, of voyeurism in the kinds of explorations that I've been talking about-the portals, the venturings, a 
hunger to find out. But more serious findings-out may come later, and when they do, it can be because what was found wasn't what was expected.

A salutary development in our time has been the discovery of how gorillas, and wolves, and cephalopods, and currently even sharks, are not in fact the dread mindless killers of humans that they were made out to be in the imperialist $19^{\text {th }}$ century (with, as an ironical counterpointing, the recognition that cuddly lovable chimps are fearsomely strong and can be lethally aggressive).

The image of the actual jungle too has changed. Sixty years ago I mentioned to Francis Huxley an article in which an explorer reported that walking in the jungle was no more dangerous than walking in a wood at home if you used common sense. And the denizens of jungles too have changed out of recognition from those mysterious drumbeating cannibals of Heart of Darkness.

It is pleasurable finding out that what from a distance, out beyond the pale, had seemed inchoate and mindless, is in fact rule-governed and informed, in a sense, by mind. That is part of what I have been reporting in this article.

Years ago, too, Thomas J. Roberts, author of the highly readable An Aesthetics of Junk Fiction (1990), remarked to me that people talk as though so-called primitive peoples were either better than us or worse than us, rather than like us.

of course a lot can be contained in that "us," unless it simply refers to civilized denizens of bourgeois academe, the end products of a long process of taming. Among the documents about "us," construed broadly, are Céline's Death on the Installment Plan, and Hubert Selby Jr's The Room, and Pauline Reage's Story of $O$, and a whole lot of other works that can't, any more than can King Lear, simply be viewed as deviations from the healthy Hoggartian norm.

When I call books with titles like Hot Dames on Cold Slabs, and Stiffs Don't Squeal, and Make Mine a Harlot novels, I'm not making a value judgment and trying to elevate them onto what is thought to be a higher sphere. I'm simply assuming that being a novel is not intrinsically meritorious, except insofar as any act of creation is, and that there are vast numbers and varieties of novels, about which, if one chooses to read this or that one, one simply has to make up one's mind as one goes along.

Nor is the Jungle a place in which what one finds is intrinsically inferior to what obtains in "real" novels, or the violences in them innately worse:

she passed out and they slapped her a few times and she mumbled and turned her head but they couldn't revive her so they continued to fuck her as she lay unconscious on the seat in the lot and soon they tired of the dead piece and the daisychain broke up and they went back to Willie the Greeks and the base and the kinds who were watching and waiting to take a turn took out their disappointment on Tralala and tore her clothes to small scraps put out a few cigarettes on her nipples pissed on her jerked off on her jammed a broomstick up her snatch then bored left her lying amongst the broken bottles and rusty cans of the lot ...

The passage comes from Hubert Selby, Jr's Last Exit to Brooklyn (1964). I could have quoted worse ones from his The Room (1971).

During the Lady Chatterley trial in England in 1960, the Crown Prosecutor famously asked the jury whether they would want their servants to read such a book. There seems to me to have been a snobbery like that at work in some of the recoil from the Junglies, which were being read and enjoyed and passed from hand to hand by workingmen. 

Web. them.

\section{LVIII}

But why oh why (one hears the plaintive question) do there have to be such violences in "entertainment" works at all?

Back in 1974, when I was younger and brighter, I devoted a whole book to the subject of violence (Violence in the Arts, Cambridge U.P.), and it was well received by some eighty reviewers, so it evidently wasn't beyond the pale. In it I attempted a lot more in the way of distinctions between different kinds of violence than I've had room for here.

Those were simpler and more innocent times back then, before all the portals on the

But it is noteworthy how the American young nowadays, after having been brought up for the most part in ways calculated to raise their self-esteem, and reassure them about the benigness of their world, and the goodness of their fellow humans, and the wrongness of anger, and hatred, and aggression, and the needlessness of violence, have flocked to horror series like Halloween, and Nightmare on Elm Street, and Friday the Thirteenth, with theirserial killers, and to all those movie descendants of The Texas Chain Saw Massacre in which more or less normal young people pass too heedlessly through portals, up to and including those in Hostel, in which horrible things happen to some of

The young know that the world, as reported on the Box, and experienced terribly at times by flesh-and blood individuals, is not a safe place now, any more than it was during my boyhood in the Thirties, and is not going to become one; as was known back in the Golden Age of late Victorian and Edwardian England by writers like Wells (not a proponent of chivalrous combat) and Conan Doyle, the latter with a wider and more disturbing repertoire of violences than those dealt with by Holmes, including, as did the oeuvres of Rider Haggard, Kipling, and Buchan, torture.

In an age of wildly conflicting "authoritative" versions of truth, a solipsistic indifference to accuracy, and an interminable clatter of ideologies, often tyrannical in their empowering of bureaucrats, and at times at so tertiary a level that arguing with them is virtually impossible, escaping back into scenarios like those that I've talked about can be an escape into unmonitored freedom and primary feelings, a realm in which, as during the processes of sleep, the nature of the everyday and the supposedly natural can be reconfigured.

There may even be paths that can be traced from Orwell's ambiguous relationship with Yank Mags in the Thirties, while he was trying to break free from the ideology of the imperialism of which he had been a flag-saluting and, by proxy, buttocks-flogging agent, and his subsequently being able to keep his distance from the What Every Decent Person Knows orthodoxy of British liberal-left Marxism 
We might bear in mind, too, that part of what made 1984 so powerful an indictment of the awfulness of the totalitarian state was that hungry rat in Room 101 gazing from inches away into the eyes of the terrified Winston Smith, a rat derived from Sax Rohmer's melodramatic near-pulp novel The Return of Dr. Fu-Manchu (1916), which may have derived its own rat torture from Octave Mirbeau's The Torture Garden (1899), which in turn may have been obliquely connected with the Dreyfus affair.

February 2012

\section{Part 5}

\section{Notes} Sarto's Lady Don't Fall Backwards. The instant friendly laugh of audience recognition on the LP suggests a persisting memory of Darcy Glinto's scandalous Lady-Don't Turn Over (1940), linked here with Ben Sarto's disreputable Miss Mabie Otis. But the book in the episode is obviously just a conventional whodunnit.

\section{Steve Holland} scholarship in The Mushroom Jungle; a History of Postwar Paperback Publishing (1993) and the poignant The Trials of Hank Janson (2004). His suggestion about Orwell hating Americans is in his Mean Streetmaps; Essays into Crime (Bear Alley, 2011), 48.

\section{Allen J. Hubin}

Allen J. Hubin's Crime Fiction IV; a Comprehensive Bibliography 1749-2000 (Locus Press, 2005) is an amazing CD-ROM.

\section{Representative samples}

In my website I suggest that:

My handful of samples from the Jungle may be more representative than I supposed. I see that between them those authors wrote over four hundred of the books (not including Frances' Hank Jansons) bearing the following pseudonyms: Dail Ambler, Ace Capelli, Ricky Drayton, Johnny Cello, Max Clinton, Earl Ellison, Griff, Victor Hanson, Duke Linton. Steve Markham, N. Wesley Firth, Kirk Medusa, Spike Morelli, Nick Perrelli, Nat Karta, Ben Sarto, Dale Shannon, Hank Spencer, Danny Spade, Brett Vane, Vernon Warren, Hyman Zore.

Which is to say that they wrote over half of the some eight hundred books that I've listed, of which, including the Kellys, I've read getting on for a couple of hundred.

The principal libraries with Jungle holdings (see COPAC online) are the British Library, the Oxford University Libraries, and Trinity College, Dublin. The most complete holdings are likely to be in the collections of one or two aficionados who began buying before the books became collectibles. 
514 It's possible, of course, that such copies as I was able to acquire myself during the past decade or so were survivors, and that spicier and more sadistic works disintegrated during their alleged passage from hand to hand. But there is a lot of variety in the some 130 works of which I provide descriptions in "Mushroom Jungle Books: II." (Found Pages>Sidebars) http://www.jottings.ca/john/kelly/sbar12b.html

\section{Hoggart's texts}

516 The information about the creation by Hoggart of the texts and names in The Uses of Literacy comes from Sue Owens, "The Abuse of Literacy and the Feeling Heart," Cambridge Quarterly (vol 34, issue 2, 147-76).

\section{7 "Violence, Inc"}

518 Among the items in Found Pages is "Violence, Inc," in which I list for each year from 1899 to 1975 a variety of more or less violent works that appeared in it, along with visuals and, up to 1939 , significant political events.

\section{Orwell texts}

The Orwell texts that I refer to are in The Complete Works of Gorge Orwell, ed. Peter Davison, assisted by Ian Angus and Sheila Davis (London, Secker and Warburg, 1986-1998).

\section{Thrillers}

Thrillers elsewhere on my website, which I put together before stepping through the Jungle portal, contains a lot about mainstream thrillers that I have enjoyed for over half a century. http://www.jottings.ca/john/thriller_main.html

\section{3 "Some Orchids"}

For my comments on No Orchids, see "Some Orchids for James Hadley Chase," which includes information about textual variations. http://www.jottings.ca/john/kelly/ sbar1.html

\section{Yanks}

"Even if you steer clear of Piccadilly with its seething swarms of drunks and whores, it is difficult to go anywhere in London without having the feeling that Britain is now Occupied Territory. The general consensus of opinion seems to be that the only American soldiers with decent manners are the Negroes. ...

Before the war there was no popular anti-American feeling in this country. It all dates from the arrival of the American troops, and it is made vastly worse by the tacit agreement never to discuss it in print. ... Even such a fundamental difficulty as the fact that an American soldier's pay is five times that of a British soldier has never been properly ventilated."

George Orwell, "As I Please," Tribune, December 3, 1943; XVI, 12.

\section{Unarmed combat}

The Fairbairn and Sykes material comes from "Quotes on W.E. Fairbairn, E.S. Sykes and Dermot 'Pat' O'Neill," 2000, www.kgutterfighting.org.

Unarmed combat was among the subjects taught in the Home Guard training programmes at Osterley Park and three other establishments, set up initially by Orwell's friend Tom Wintringham, later one of the founders of the Common Wealth party. I imagine it was along the Fairbairn-Sykes lines.

Sykes instructed in the second-stage toughening school of the elaborate four-stage S.O.E. (Strategic Operations Executive) training programme for agents who would help 
to organize the Resistance in Hitler's Europe after it became clear in 1941 that the invasion of England was off. America's O.S.S., which cooperated with and learned from S.O.E., adopted its unarmed combat techniques. See S.O.E. Assignment (New English Library, 1975) by Donald Hamilton-Hill, a senior member of the organization.

Fairbairn's Get Tough!; How to Win in Hand-to-Hand Fighting; as taught to the British Commandos and the U.S. Armed Forces (1942), with its don't-try-these-on-yourschoolmates illustrations, would have been widely distributed. I saw a copy myself in school.

\section{Michael Powell}

Michael Powell and Emeric Pressburger, directors, The Life and Death of Colonel Blimp (1943), with Roger Livesey, Deborah Kerr (in three roles), and Anton Walbrook, one of the great colour movies.

Reportedly Churchill hated it, unseen, because of its implied casting of doubt on the quality of British generals; which, if so, would be ironical, given his own low opinion of a lot of them. The movie is a loving, unhurried, civilized celebration of English chivalric values (not the strutting, sabre-duelling Prussian kind), and a defining of limitations in them, and ends with the promise of a creative interaction when Major-General Clive Wynne-Candy (ret.) takes (as he announces) his brash young war-games nemesis to dinner at his club. The beautfully under-playing Walbrook was a salutary reminder that Germans and Nazis were not synonymous.

In wartime movies like Colonel Blimp, A Canterbury Tale (1944)and I Know Where's I'm Going (1945), Powell and Hungarian-born Pressburger had memorably defined some "English" values, quieter than the Laurence Olivier kind, that were worth fighting for. When in 1960 (the year of outrage against Georges' Franju's horror classic Les Yeux sans Visage when it was shown at the Edinburgh Festival), Powell presented a very different England in Peeping Tom, the journalistic fury effectively ended his career.

This was at the end of a decade during which the British government, with its concentration camps, tortures, and summary executions, had put down the Mau-Mau movement in Kenya with German savagery and, at home, French lying and stonewalling (this was the Algeria decade), in one of the worst episodes in British colonial history. On which see Caroline Elkins' Imperial Reckoning; The Untold Story of Britain's Gulag (2005).

\section{British gangdom}

537 So far as I know, the concern about American-type London gangs ca. 1929-32 was hypothetical. The figure of the American gangster as we know it did not become available for imitation in England until the coming of sound in movies, and far from their rampaging around the West End in fast cars spouting lead and tossing bombs, the East End gangs' principal sites of operation were racecourses where they competed for dominance in the protection racket (providing bookmakers with "protection" from having their stands wrecked). See Fergus Linnane's London's Underworld: Three Centuries of Vice and Crime (2003) and Robert Murphy's Smash and Grab; Gangsters in the London Underworld (1993). See also my "Gangdom." http://www.jottings.ca/john/kelly/ sbar12.html

Among the "Violence Inc" entries for 1932 is a persuasive-looking illustration from the weekly 'zine The Thriller in which four hoods with gun and cosh, and a couple more looking on from an open roadster, are beating up an unfortunate bike-riding country 
bobby. I take this to be an extrapolation from the headlined shooting of Constable Gutteridge in Essex five years earlier by a couple of English car thieves. 
by a megalomaniacal former Russian scientist (master of disguises), whose principal agents included a blind enormously strong hunchback, an American, a German, and a slinky French Countess.

All this realworld violence had been going on only forty miles away from the Leeds in which Richard Hoggart, born in 1918, was growing up, where a clever little lad, then or later, could hardly have escaped learning about some of those less pastoral aspects of working-class culture.

Sillitoe reports of the Glasgow gangs that many of them started after the War and consisted initially of unemployed youths hanging out on street corners. "They certainly were never, in any sense, organized teams of experienced criminals who grouped themselves round a "master mind." However,

The inner circle of the Beehive Gang was composed of housebreakers, and around them moved a much larger group of men who could be called upon to take part in fights, intimidations, and occasionally mob attacks and robberies. The leader of the Beehives was a man named Peter Williamson, powerfully built and in his early twenties. He came from a respectable family, had been well educated according to the standard of the district, and was a highly intelligent and fluent speaker. He could put up a creditable show defending himself in police courts and later in his career was quite frequently given opportunity to do so. $($ Ch.14, 141) circumstances.

554 Bryce Report

For the Report of the Committee on Alleged German Outrages appointed by His Britannic Majesty's government and presided over by the Right Hon. Viscount Bryce, see my "Propaganda, Atrocities, and the Limits of the Thinkable; the Bryce Reports and Others." http://www.jottings.ca/john/kelly/sbar14.html

\section{Hitler}

Natural though it is to speak of Hitler's gangsterism, I can't bring to mind actual gangs in which the boss displayed his combination of high-energy charismatic selfpresentation, stretches of chronic inertia when not "on," appalling callousness, little interest in organizational detail, and increasingly unreal abstractions from concrete

The Hitler whom we have learned more and more about in recent decades sounds adolescent-unshakably certain of the truth of his feelings, unaware of all that he didn't know, and vastly self-pitying.

Orwell, reviewing Mein Kampf in 1940, saw "the face of a man suffering under intolerable wrongs" and admits that "there is something deeply appealing about him," and that he himself couldn't feel animosity towards him (XII, 117). Given his own years of poverty and marginalization after he quit the Indian Police Service and tried to make it as a writer, with a consciousness of his eccentricity politically, there may have been some fellow-feeling there.

All of which-Hitler's character, I mean-was OK as long as what he was essentially doing up until the fall of France was brilliantly intuiting the feelings and probable 
reactions of others (his adoring audiences, his domestic and foreign opponents), but was increasingly disastrous when what counted were non-human factors like distances and temperatures during the Russian campaign.

561 At bottom his was, it would appear, an unstable and somewhat feminine psyche that felt threatened by the grounded male self-assurance of Jews (as it seemed to him), with their cohesive family warmth and group identity, and sought to compensate with a differently chosen people of his own and an imperial Roman hardness embodied in grandiose more-than-Roman architecture.

A clear indication of the intellectual decline of the British governing class was its willingness in the Thirties to ignore all the evidence about Hitler's character and the murderous cruelty of his regime-evidence that would have kept Victorian politicians like Gladstone and Disraeli from the wish-fulfilling delusion that he was "really" OK beneath the posturing.

On Hitler's gangster attire, see Niall Ferguson, The War of the World; Twentieth-Century Conflict and the descent of the West (Penguin, NY, 2006), 233:

In Munich in the early 1920 s he could be seen attending the soirees of a Romanian princess "in his gangster hat and trenchcoat over his dinner jacket, touting [toting?] a pistol and carrying as usual his dog-whip."

\section{Harry Fabian}

"Every film he had ever seen, and every book he had ever read, rushed together in his brain to form one blazing and magnificent composite, in which he, Fabian, fantastically enlarged, fantastically dressed, leaned backwards in a wild photomontage of champagne bubbles, limousines, diamonds, galloping horses, baize tables, and beautiful women, all whirling and weaving in a deluge of white and yellow chips, and large bank notes, an eternal reduplication of breasts and legs of every conceivable shape, size, and colour. ..." (ch. 21, 336-37)

"He loved this game [of poker dice], which smacked somehow of the gangster films, about which he had constructed all those elaborate affectations which went to build up his life." (ch. 25, 358)

Gerald Kersh, Night and the City (Simon and Schuster, 1946 [1938])

\section{Peter Cheyney}

"Cheyney's books were immensely popular with service men and prisoners of war." Clive Bloom, Bestsellers; Popular Fiction Since 1900 (London, 2002)

\section{Lee Horsley}

Surprisingly, in her comments on No Orchids in The Noir Thriller, Lee Horsley uses, without mentioning the fact, the heavily revised and softened Panther/Penguin edition (1961/1980). On the five (at least) different texts of the novel, see section XVI of my "Some Orchids for James Hadley Chase." For me the first edition is the best, and it is the one that Orwell was using.

http://www.jottings.ca/john/kelly/sbar1.html

\section{Maureen Waller}

Maureen Waller's London 1945; Life in the Debris of War (2004) is excellent on postwar shortages and frustrations.

\section{George Ryley Scott}

On George Ryley Scott, see my Note 25, "George Ryley Scott." http://www.jottings.ca/ john/kelly/notes.html\#25 


\section{Austerity Britain}

David Kynaston provides a lot of information in his almost 700-page Austerity Britain, 1945-51 (2007), but quite a bit of it seems derived from surveys conducted with studied neutrality by researchers for Mass Observation. There is very little in it about sex and movies, America doesn't appear in the index, and Hoggart makes a brief appearance on one page in connection with tasty food.

\section{Kelly mystery}

I know nothing about the creation of Lady-Don't Turn Over, issued, like the five other pre-trial Glintos, by a respectable and well-established publisher.

I have learned nothing leading up to it about Kelly himself, beyond his having been born in 1899 (a year after my father) in a large Catholic family, helping create in 1932 the City of London newspaper City Mid-Week, that was put out of business the following year in a libel action, editing later in the Thirties the prose of some self-development publications by his friend the former world-champion wrestler George Hackenschmidt, and living, when Lady appeared in 1940, near Romford, a centre of the emergent black market.

79 He had done cultural reviewing in City Mid-Week, a play of his was performed in 1933 by a London group with "name" actors in it, and in his sixties, as remembered by a woman who knew him for several months in the Canary Islands, spoke excellent French and was widely read. According to his introduction to his London Cameos (1951), he was a working journalist when City Mid-Week was started. The same woman recalls him telling her that he was in the Merchant Marine (with no details) sometime between the wars. I don't know if he was in the Great War, or, more importantly, if he was ever in North America, though it seems likely.

No photo of him has surfaced, though I have guessed that he figures in a drawing. http://www.jottings.ca/john/kelly/notes.html\#40

582 Michael Barnes

I've had the pleasure of a correspondence with the daughter of one of the Jungle authors, Michael Barnes, who wrote forty or more novels as Whitney Brown, Ricky Drayton, Frank Hanson, Karl Medusa, Johnny Cello, Max Clinten, Hyman Zore, and himself, and later went into film work. 


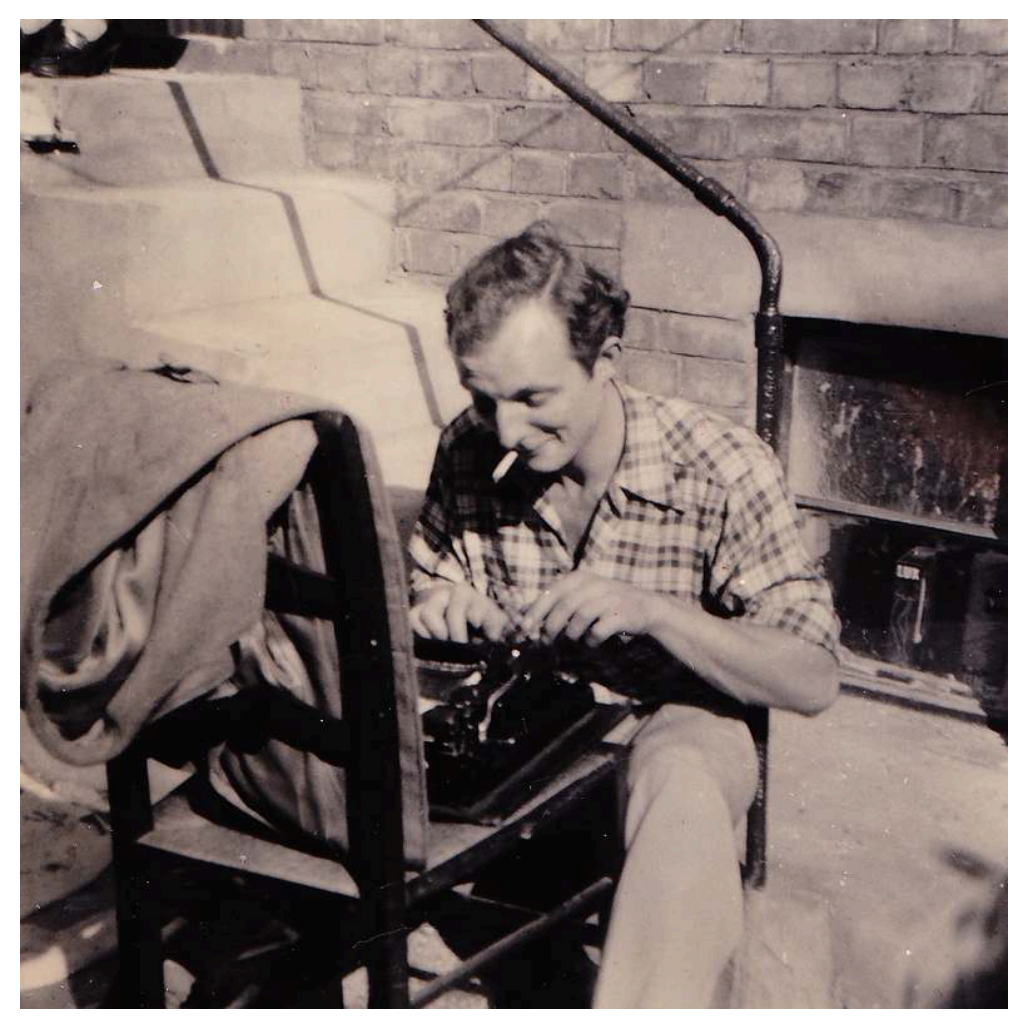

Michael Barnes.

Reproduced by kind permission of Luci Gorell Barnes.

He was twenty when he was demobbed from the Navy at the end of the war, and he and his young wife were able to live frugally in Spain and Morocco on what he got for those forty-some books that took, apparently, about ten days each to write, this at a time of currency restrictions that made getting out of England, let alone to the Med, like escaping through the Iron Curtains. See Note 4 and my description in "Junglies II" of The Unsuspected, written before I knew these facts.

http://www.jottings.ca/john/kelly/sbar12notes.html\#4

http://www.jottings.ca/john/kelly/sbar12b.html

What bliss to be young and a writer living on the Med in those grey years. I wonder how many other young Junglie writers there were.

\section{Stephen Frances}

The working-class-born Stephen Frances, as described in Steve Holland's fascinating The Trials of Hank Janson, wrote a prodigious number of books as Janson and twenty-four others, sold in great quantities, earned a great deal of money (on paper), was cheated blind by business associates (he evidently had lousy judgment), and died poor in Spain.

A disadvantage to a first-person series narrator like "Hank Janson" is that one knows that Hank will always survive to narrate more episodes, and his character is likely to fluctuate in the interests of variety. Personally I don't find him particularly interesting, and his eye for the glimpses of flesh above the stocking tops of office-workers becomes irritating. But I wonder what gems, however rough, are still blushing unseen in Frances' oeuvre. Several well-made Jansons in the 1960s are very probably by Kelly.

\section{$591 \quad$ La Guerra}




\section{Glinto bowdlerized}

It is very difficult now to access the unbowdlerized first edition of Lady-Don't that descended like manna for me in that boarding-school locker. A copy which I was able to buy in the Seventies is now so fragile as to be unusable, but Steve Holland kindly sent me a photocopy.

That was the Wells, Gardner edition of 1940, withdrawn from circulation as a result of the old Bailey trial in 1942. The later Robin Hood editions are without the bits, some just a sentence or two, found criminally offensive by the Crown, and in one of the texts a long passage has been added about the psychology of gang-leader Dill slitson.

In the first printed version of "Raffles and Miss Blandish," Orwell assumed that LadyDon't was a James Hadley Chase novel, and that it was this rather than Miss Callaghan Comes to Grief that brought Chase "to the attention of the authorities."

The Robin Hood edition of the banned Wells, Gardner Road Floozie (1941) is also bowdlerized, and the Wells, Gardner edition is virtually impossible to get hold of.

I talk about these matters in "Chase and Glinto" and "Early Glinto," in the latter of which I provide some of the material excised from Road Floozie.

http://www.jottings.ca/john/kelly/sbar2.html

http://www.jottings.ca/john/kelly/sbar3.html

In "Scandal" I give some information about the trial and the excisions, and provide the passages that Hoggart appeared to be drawing on for his composite passage.

http://www.jottings.ca/john/kelly/sbar8.html

\section{Kelly's Westerns}

Kelly, especially, isn't noir, even when things go badly for characters. Clare Holding in Lady doesn't surrender her inner self to Slitson, in contrast to Miss Blandish's relationship with Slim. Eileen Rourke in Road Floozie is feisty all the way through. Carrie Donovan and Connie O'Mara run their respective gangs in a way that obviously helped to generate Modesty Blaise. And so on.

The Robin Hood Westerns remain a puzzle for me. The ones by Lance Carson seem largely by Kelly, and the ones by Clinton Wayne and Bryn Logan overlap with them in various ways. Like Darcy Glinto's Deep South Slave (1951), a number of them are crafted with care, especially in comparison with various Glintos appearing around the same 
time and obvious pot-boilers. They also display a good deal of what feels like first-hand knowledge of Western terrains.

But biographical information about Kelly is so hard to come by that I still have no certain knowledge about whether he was in North America, or, if so, for how long. The interminable biographical speculations about Shakespeare shed almost no light on the plays that matters, except for the identifying of possible allusions in them. But the facts of Kelly's life are bound up with the question of the authorship of a number of the works.

See Sidebar 9, "Westerns". http://www.jottings.ca/john/kelly/sbar9.html

\section{Apollinaire}

For a translation of "Lul de Faltenin," go to Apollinaire at http://www.jottings.ca/john/ voices/newbk_contents.html.

For a note about it, see http://www.jottings.ca/john/voices/ newbk_notes.html\#Apollinaire.

\section{Pre-1914 Americanization}

615 There had been no major problems with Americanism before the Great War, apart from Irish-American support for the Irish rebels.

616 America was the domain of rich beautiful heiresses ready to be married to impoverished members of the British aristocracy; and inventions like telephones, and electric lighting, and typewriters, and the Morse Code, and the Maxim gun (for dealing with Fuzzy-Wuzzies), and the Panama Canal, and Kodak cameras and philanthropic millionaires like Andrew Carnegie, and the humour and boyhood charm of Mark Twain, and a shared love of Kipling. And, unlike the Kaiser's, its navy wasn't competing with Britain's for a place in the imperial sun.

617 In H.G. Wells' Tono-Bungay (1909), the Wellsian narrator, his mother the housekeeper of an aristocratic country house, escapes from the stasis of the class system via his very "American" uncle, engages enthusiastically with him in the marketing of a wholly bogus patent medicine, makes a foray into equatorial Africa after radioactive mud, shoots an inoffensive native, in anticipation of Camus' L'Etranger, and ends up roaring seaward down the Thames in a destroyer of his designing.

618 And Shaw, in Major Barbara, after sending up the aristocracy, and the Classics, and religion, brings his own now drifting symbolic characters back down to the Americanstyle base of an efficiently run and morally neutral armaments business.

\section{Wells and Kipling: portals}

Wells, of course, was in his early works a major creator of portals, of openings into the strange, the imperfectly glimpsed, the dangerous, in works like The Time Machine, The First Men in the Moon, The War of the Worlds, The Island of Doctor Moreau, "In the Abyss," "The Sea Raiders."

So was Kipling, but whereas the marvels and mysteries of Wells all cohere as parts of a common and intelligible world extended in a variety of directions, those of Kipling, particularly in his weaker later works, do not. He was a master-illusionist of arcane knowledge, whether about mysterious India, or mind-altering technology, or the supernatural more generally, narrating as though the rules of the various games, which often were his own invention, were common knowledge and not in need of explanation. 
And when a character is doing the narrating, as with the ghost story "At the End of the Passage," or that powerful story of prehistoric sea creatures "A Matter of Fact," you have the feeling that even if what you're reading is fiction, you are getting glimpses of places or circumstances in which l'insolite, the strange, could happen. Kipling was very fin-de-siècle.

\section{George Sturt}

George Sturt himself, as the young would-be-literary inheritor of a wheelwright business in Surrey, had been greatly indebted, as his journals show, to the self-reliance celebrated by Emerson and Thoreau. He was explicit in Change in the Village (1912) about not being on a nostalgic time-trip. See my "Reflections on the Organic Community," The Name of Action (Cambridge, 1984).

\section{$625 \mathrm{JF}$ on violence and order}

I have written a good deal about aspects of violence, power, and order, what with Violence in the Arts (1974), America and the Patterns of Chivalry (1982), and, two years later, The Name of Action;Critical Essays (all three published by Cambridge University Press), plus, on the Web, Thrillers, Found Pages (in effect a whole book on Kelly), and Mushroom Jungle Books.

This doesn't mean that if I hadn't been allowed to burrow among all those nasties as a boy, I would have grown up nice and civilized and pastoral. It's rather, as I've tried to show here, that the kinds of things that I've talked about connect up with the real world of politics and social organization.

Violence in the Arts began as a long article that I wrote in 1966 in a Provençal village when I was trying to get my bearings among the new-style violences of that decade and the claims being made about revolutionary new sensibilities, plus the Frenchintellectual prestige of Sade.

And in America and the Patterns of Chivalry, which I stumbled into under the impression that it would be a short follow-up to Violence in the Arts in which I would deal with the nature of peace-preserving agonistic structures, I found myself trying to fit together some of the values of "peace" and "war", and ended up with what came to seem to me later like a sort of unified field theory.

\section{Hong Kong movies}

631 Thanks to a Chinese grocery store a couple of blocks away, I was able for several years, starting in 1991, to rent over a thousand Hong Kong movies. There were rarely descriptions in English on the boxes, or pictures, and a lot of the movies didn't have subtitles. For most of that time, I read nothing about them, though I shared some opinions with the poet Dave McGimpsey. So I often didn't know whether I was getting triads, comedies, kung-fu, historical, police, horror, supernatural.

There were wide variations of styles and quality-extreme violence at times-cruel gangsters, serial killers. It was all a dense world of night clubs, crowded streets, winding hill roads, waterfronts, and I created for my own satisfaction a descriptive computer filmography of nine-hundred-and-twenty movies.

It was the most exciting movie-viewing experience of my life, and I imagine that some of that kind of excitement was available to readers of a lot of Jungle books.

\section{Blake}


"You never know what is enough unless you know what is more than enough." (William Blake, "Proverbs of Hell.")

\section{Part 6}

\section{Bibliography}

In the text, for works that are simply alluded to by title, I've provided the date of first publication or first movie release. When I quote, except with Orwell, I give page numbers and chapter numbers. In the Bibliography I provide the names of publishers for secondary works and for novels that I've quoted from or that I discuss at some length.

In practice, Jungle titles are now so hard, and at times so expensive, to get hold of that the names of publishers, except with Chase and Glinto, don't matter. I mean, any texts, when they turn up, are to grab. A few Junglies were reprinted in the States, chiefly, I think by Leisure Library, whose copies bear the words, "Edited by Lewis Thompson." To judge from how bad one of them is, the editing, if there was any, must have been light indeed. Nor has spelling been Americanized.

For Orwell, all references are to The Complete Works of George Orwell, ed. Peter Davison, assisted by Ian Angus and Sheila Davison (Secker and Warburg, 1986- ), and include volume numbers.

There is lots of material on my website, Found Pages, including, in "Jungle Books" part 1, some information about pseudonyms. But for them, and much else, one is best off going to Hubin.

\section{BIBLIOGRAPHIE}

\section{Primary Sources}

ORWELL, George, Down and Out in Paris and London (1933), The Complete works of George Orwell, Peter Davison, ed., vol. I, London, Secker \& Warburg, 1986.

---, The Road to Wigan Pier (1937), The Complete works of George Orwell, Peter Davison, ed., vol. V, London, Secker \& Warburg, 1987.

---, Coming Up for Air (1939), The Complete works of George Orwell, Peter Davison, ed., vol. VII, 1, London, Secker \& Warburg, 1987.

Other:

Volume X: A Kind of Compulsion, 1903-1936.

“Clink," August 1932, 254-61 (254).

Letter to Rayner Heppenstall, October 5, 1935, 399. 
Review in New English Weekly, April 23, 1936 of five books, including Paul Cain's Fast One, 474-76

(475).

Book review, Time and Tide, November 21, 1936, 522-24 (523).

Volume XII: A Patriot After All, 1940-1941.

“Boys' Weeklies," March 11, 1940, 57-79.

"Inside the Whale," March 11, 1940, 86-115 (90).

Review of Mein Kampf, New English Weekly, March 31, 1940, (116-18).

Book review, Tribune, April 12, 1940, 142-44 (143).

Orwell and the Home Guard; lecture notes for instructing the Home Guard, 1940-1942), 328-40.

Volume XVI: I Have Tried to Tell the Truth, 1943-1944.

"Mark Twain-The Licenced Jester," Tribune, November 26, 1943 (7).

Letter to Dwight Macdonald, December 11, 1943, 24-25.

Book review (71).

Reply to Vera Brittain in “As I Please," Tribune, July 14, 1944 (196).

“Raffles and Miss Blandish," Horizon, August 28, 1944, 345-58 (352).

FRASER, John, Violence in the Arts, illustrated edition, London, Cambridge U.P., 1976 [1974].

---, America and the Patterns of Chivalry, Cambridge, Cambridge U.P., 1982.

---, Found Pages>Sidebars, http://www.jottings.ca/john/kelly/sbar1.html.

"Jungle Books," Parts 1 and 2

"Some Orchids for James Hadley Chase"

"Early Glintos"

"Kelly Brothers"

"Scandal"

---, Found Pages>Notes, http://www.jottings.ca/john/kelly/notes.html.

55. Kelly birthplaces

66. Biographical information

---, Thrillers>“Reading Thrillers”, http://www.jottings.ca/john/thriller_read.html

Secondary Sources

BEAN, J.P., The Sheffield Gang Wars, Sheffield, D. \& D. Publications, 1981.

BLOOM, Clive, Bestsellers: Popular Fiction Since 1900, Basingstoke, Palgrave, 2002.

CARY, Joyce, Art and Reality; Ways of the Creative Process, Garden City, Doubleday Anchor Books, 1961 [1958].

DAVIS, Wade, Into the Silence: the Great War, Mallory, and the Conquest of Everest, Westminster, Knopf, 2011.

FAIRBAIRN, W.E., Get Tough! How to Win in Hand to Hand Fighting: as taught to the British Commandos and the U.S. Armed Forces, New York, Appleton-Century, 1942. 
FAIRBAIRN, W.E. et. al., “Quotes on W.E. Fairbairn, E.S. Sykes and Dermot 'Pat' O'Neill,” http:// www.gutterfighting.org/FairbairnSykesONeill.html.

GREENE, Graham, A Sort of Life, New York, Simon and Schuster, 1971.

HAINING, Peter, The Classic Era of American Pulp Magazines, Chicago, Prion, 2000.

HAMILTON-HILL, Donald, SOE. Assignment, London, New English Library, 1975 [1973].

HILL, Billy, Boss of Britain's Underworld, London, Naldrett Press, 1955.

HOGGART, Richard, The Uses of Literacy; Aspects of Working-class life, with special reference to publications and entertainments, London, Chatto and Windus, 1967 [1957].

HOLLAND, Steve, Mean Streetmaps, Colchester, Bear Alley, 2010.

---, The Mushroom Jungle; a History of Postwar Paperback Publishing, Westbury, Zeon, 1993.

---, The Trials of Hank Janson, Tolworth, Telos, 2004.

HORSLEY, Lee, The Noir Thriller, Basingstoke, Palgrave, 2001.

HUBIN, Allen J., Crime Fiction IV; a Comprehensive Bibliography 1749-2000, Oakland, Locus Press, 2005.

JONES, Robert Kenneth, The Shudder Pulps; a History of the Weird Magazines of the 1930s, West Linn, FAX Collector's Editions, 1975.

KNYASTON, David, Austerity Britain 1946-51, London, Bloomsbury, 2007.

LEAVIS, F.R., The Great Tradition, London, Chatto \& Windus, 1948.

LEAVIS, F.R. and Denys THOMPSON, Culture and Environment, London, Chatto \& Windus, 1933.

LINNANE, Fergus, London's Underworld; Three Centuries of Vice and Crime, London, Robson Books, 2003.

LOVISI, Gary, Dames, Dolls and Delinquents; a Collector's Gude to Sexy Pulp Fiction Paperbacks, NY, Krause, 2009.

MALCOM, Norman, Ludwig Wittgenstein: a Memoir, London, Oxford U.P., 1958.

MURPHY, Robert, Smash and Grab: Gangsters in the London Underworld 1920-60, London, Faber, 1993.

OWEN, Sue, "The Abuses of Literacy and the Feeling Heart: The Trials of Richard Hoggart,"

Cambridge Quarterly, vol. 34, $\mathrm{n}^{\circ}$ 2, 2005, 147-76.

POUND, Ezra, $A B C$ of Reading, London, Routledge, 1934.

SCHMIDT, Franz, A Hangman's Diary: Being the Journal of Master Franz Schmidt, Public Executioner of Nuremberg, 1573-1617, Albrecht Keller, ed., trans C. Calvert and A.W. Gruner, with an introductory essay by C. Calvert, New York, Appleton, 1928.

SCHOENBERG, Robert J., Mr. Capone, New York, Perennial, 1992.

SCOTT, George Ryley, Into Whose Hands: an Examination of Obscene Libel in its Legal, Sociological and Literary Aspects, London, Gerald G. Swan, 1945.

SILLITOE, Percy, Cloak Without Dagger, London, Pan, 1956.

STREATFIELD, D., Persephone: A Study of Two Worlds, New York, Julian Press, 1959.

THOMAS, Donald, An Underworld at War: Spivs, Deserters, Racketeers and Civilians in the Second World War, London, John Murray, 2003. 
TIMPERLEY, H.J., compiler and editor, What War Means: The Japanese Terror in China, a Documentary Record, London, Gollancz, 1938.

VANSITTART, Robert, Black Record; Germans Past and Present, London, Hamish Hamilton, 1941.

WALLER, Maureen, London 1945: Life in the Debris of War, London, John Murray, 2004.

World Committee for the Victims of German Fascism, The Brown Book of the Hitler Terror and the Burning of the Reichstag, intro. Lord Marley, London, Gollancz, 1933.

Fiction

ANGEL, Ross, Tomorrow the Chair, London, Scion, 1950.

BOGARD, Dale, Nobody Died for Johnnie, Manchester, World Distributors, 1951.

CAPELLI, Ace [Stephen Frances], Get Me Headquarters, intro Steve Holland, New York, Gryphon, 1996 [1949].

CHARTERIS, Leslie, The Saint's Getaway, NY, Charter, n.d.

CHASE, James Hadley, Miss Callaghan Comes to Grief, US, Olympia, 2010 [1941].

---, No Orchids for Miss Blandish, London, Jarrolds, n.d. [1939].

CHEYNEY, Peter, This Man is Dangerous, London, Fontana, 1954 [1936].

COE, Charles Francis, Gunman, London, Gollancz, 1930.

DELUZ, Maria [Stephen Frances], In the Hands of the Inquisition, London, Canova, 1971.

ELLIOTT, William J., Freak Racket, London, Gerald G. Swan, 1950 [1941].

---, Snatched Dame, London, Gerald G. Swan, 1948 [1942].

FORESTER, C.S., Plain Murder, London, Pan, 1970 [1930].

FRANCES, Stephen D., La Guerra: a Spanish Saga, NY, Delacorte, 1970.

GLINTO, Darcy [Harold Ernest Kelly], Lady-Don't Turn Over, London, Wells, Gardner, 1940.

---, No Mortgage on a Coffin, London, Wells, Gardner, 1941.

---, You Took Me, Keep Me, London, Wells, Gardner, 1941.

---, Road Floozie, London, Wells, Gardner, 1941.

GREENE, Graham, The Confidential Agent: an Entertainment, intro. Graham Greene, London, Heinemann, 1971 [1939].

---, A Gun for Sale, London, Penguin 1963 [1936].

JÜNGER, Ernst, On the Marble Cliffs, tr. Stuart Hood, Norfolk, New Directions, 1947 [1939].

KARTA, Nat, Love Me Hurt Me, London, Scion, 1952.

---, The Foolish Virgin Says No, London, Scion, 1953.

KERSH, Gerald, Night and the City, London, Michael Joseph, 1938.

KOESTLER, Arrival and Departure, Harmondsworth, Penguin, 1969 [1943].

LATIMER, Jonathan, The Dead Don't Care, New York, Crime Club, 1938.

---, The Latimer Big Three [The Lady in the Morgue, The Dead Don't Care, Murder in the Madhouse], New York, Sun Dial Press, 1940. 
---, Solomon's Vineyard, New York, International Polygonics, 1988 [1941].

McCOY, Horace, No Pockets in a Shroud, New York, Midnight Classics, 1998 [1937].

MORELLI, Spike, You'll Never Get Me, Cleveland, Kaywin, 1952 [Archer].

PINTER, Harold, The Homecoming, London, Eyre Methuen, 1967.

“Sapper”, The Black Gang, London, Hodder and Stoughton, 1922.

SARTO, Ben, Miss Otis Comes to Piccadilly, London, Modern Fiction [1946].

SELBY, Hubert, Jr., Last Exit to Brooklyn, New York, Grove, 1965 [1964].

STORME, Michael, Hot Dames on Cold Slabs, Lewis Thompson, ed., NY, Leisure Library, 1952.

THOMSON, Christine Campbell, ed., Switch on the Light, London, Selwyn and Blount, 1928.

VANE, Brett, Goodbye, Honey, London, Curtis Warren, 1952.

---, Sunny, London, Curtis Warren, 1953.

---, This Honey is Mine, $10^{\text {th }}$ ed., London, Curtis Warren, n.d..

VANE, Roland, White Slave Racket, NY, Leisure, 1952 [1949].

WALLACE, Edgar, On the Spot, London, John Long, n.d. [1931].

---, When the Gangs Came to London, Garden City, Doubleday, Doran, 1932. 